\title{
Quantification of human enteric viruses as alternative indicators of fecal pollution to evaluate wastewater treatment processes
}

 \\ Diaz ${ }^{\text {Corresp. } 1}$ \\ ${ }^{1}$ Department of Microbiology, University of Manitoba, Winnipeg, Manitoba, Canada \\ Department of Civil Engineering, University of Manitoba, Winnipeg, Manitoba, Canada \\ Corresponding Author: Miguel I Uyaguari-Diaz \\ Email address: Miguel.Uyaguari@umanitoba.ca
}

We investigated the potential use and quantitation of human enteric viruses in municipal wastewater samples of Winnipeg (Manitoba, Canada) as alternative indicators of contamination and evaluated the processing stages of the wastewater treatment plant. During the fall 2019 and winter 2020 seasons, samples of raw sewage, activated sludge, effluents, and biosolids (sludge cake) were collected from the North End Sewage Treatment Plant (NESTP), which is the largest wastewater treatment plant in the City of Winnipeg. DNA (Adenovirus and crAssphage) and RNA enteric viruses (Pepper mild mottle virus, Norovirus genogroups GI and GII, Rotavirus Astrovirus, and Sapovirus) as well as the uidA gene found in Escherichia coli were targeted in the samples collected from the NESTP. Total nucleic acids from each wastewater treatment sample were extracted using a commercial spin-column kit. Enteric viruses were quantified in the extracted samples via quantitative PCR using TaqMan assays.Overall, the average gene copies assessed in the raw sewage were not significantly different ( $p$-values ranged between 0.1023 and 0.9921 ) than the average gene copies assessed in the effluents for DNA and RNA viruses and uidA in terms of both volume and biomass. A significant reduction ( $p$-value $\leq 0.0438$ ) of Adenovirus and Noroviruses genogroups GI and GIl was observed in activated sludge samples compared with those for raw sewage per volume. Higher GCNs of enteric viruses were observed in dewatered sludge samples compared to liquid samples in terms of volume (g of sample) and biomass (ng of nucleic acids). Enteric viruses found in gene copy numbers were at least one order of magnitude higher than the $E$. coli marker uidA, indicating that enteric viruses may survive the wastewater treatment process and viral-like particles are being released into the aquatic environment. Viruses such as Noroviruses genogroups $\mathrm{Gl}$ and GII, and Rotavirus were detected during colder months. Our results suggest that Adenovirus, crAssphage, and Pepper mild mottle virus can be used 
confidently as complementary viral indicators of human fecal pollution. 
1 Quantification of human enteric viruses as alternative indicators of fecal pollution to

2 evaluate wastewater treatment processes

3 Audrey Garcia ${ }^{1 *}$, Tri Le ${ }^{1 *}$, Paul Jankowski ${ }^{1 a}$, Kadir Yanaç ${ }^{2}$, Qiuyan Yuan ${ }^{2}$ and Miguel Uyaguari-

$4 \operatorname{Díaz}^{1 \wedge}$

$5{ }^{1}$ Department of Microbiology, Faculty of Science, University of Manitoba, Winnipeg, MB,

6 Canada R3T 2N2

$7 \quad 2$ Department of Civil Engineering, Price Faculty of Engineering, University of Manitoba,

8 Winnipeg, MB, Canada R3T 2N2

9

$10 *$ These authors contributed equally to this work.

11

12 a Current address: Department of Medical Microbiology and Infectious Diseases, University of

13 Manitoba, Winnipeg, Manitoba, Canada

14

$15 \wedge$ Corresponding Author:

16 Miguel Uyaguari-Díaz

1745 Chancellors Circle, Buller Building, Room 414D

18 Winnipeg, Manitoba, R3T 2N2, Canada

19 Email address: Miguel.Uyaguari@umanitoba.ca 


\section{ABSTRACT}

21 We investigated the potential use and quantitation of human enteric viruses in municipal

22 wastewater samples of Winnipeg (Manitoba, Canada) as alternative indicators of contamination

23 and evaluated the processing stages of the wastewater treatment plant. During the fall 2019 and

24 winter 2020 seasons, samples of raw sewage, activated sludge, effluents, and biosolids (sludge

25 cake) were collected from the North End Sewage Treatment Plant (NESTP), which is the largest

26 wastewater treatment plant in the City of Winnipeg. DNA (Adenovirus and crAssphage) and

27 RNA enteric viruses (Pepper mild mottle virus, Norovirus genogroups GI and GII, Rotavirus

28 Astrovirus, and Sapovirus) as well as the uidA gene found in Escherichia coli were targeted in

29 the samples collected from the NESTP. Total nucleic acids from each wastewater treatment

30 sample were extracted using a commercial spin-column kit. Enteric viruses were quantified in

31 the extracted samples via quantitative PCR using TaqMan assays.

32 Overall, the average gene copies assessed in the raw sewage were not significantly different (p-

33 values ranged between 0.1023 and 0.9921 ) than the average gene copies assessed in the effluents

34 for DNA and RNA viruses and uidA in terms of both volume and biomass. A significant

35 reduction ( $\mathrm{p}$-value $\leq 0.0438$ ) of Adenovirus and Noroviruses genogroups GI and GII was

36 observed in activated sludge samples compared with those for raw sewage per volume. Higher

37 GCNs of enteric viruses were observed in dewatered sludge samples compared to liquid samples

38 in terms of volume ( $\mathrm{g}$ of sample) and biomass (ng of nucleic acids). Enteric viruses found in

39 gene copy numbers were at least one order of magnitude higher than the E. coli marker uidA,

40 indicating that enteric viruses may survive the wastewater treatment process and viral-like

41 particles are being released into the aquatic environment. Viruses such as Noroviruses

42 genogroups GI and GII, and Rotavirus were detected during colder months. Our results suggest 
43 that Adenovirus, crAssphage, and Pepper mild mottle virus can be used confidently as

44 complementary viral indicators of human fecal pollution.

45

46 INTRODUCTION

47 The human fecal waste present in raw sewage (RS) contains pathogens that can cause numerous

48 diseases. This can have a huge negative impact to public, aquatic health, and the economy

49 (Stachler, et al., 2017). Wastewater treatment plants (WWTPs) serve as protective barriers

50 between communities and the environment by reducing the organic matter present in wastewater.

51 Water quality is currently assessed using traditional markers such as coliforms and Escherichia

52 coli, leaving other microbes such as viruses largely unexplored. The North End Sewage

53 Treatment Plant (NESTP) in Winnipeg, Manitoba handles approximately $70 \%$ of the city's

54 wastewater treatment, serving over 400,000 people (City of Winnipeg, Water and Waste

55 Department, 2020). The treatment process at the NESTP first involves RS undergoing primary

56 treatment to remove solids. During the next treatment cycle, activated sludge (AS), a

57 heterotrophic cocktail of bacteria and protozoa, degrades organic matter present in solid waste.

58 The activated sludge (also known as biological treatment or secondary treatment) is the most

59 widely used process around the world to treat municipal wastewater (Racz et al., 2010; Scholz,

60 2016), and its use will likely continue due to its low cost and high efficiency. After the biological

61 treatment, wastewater is UV-disinfected and discharged as effluents (EF) into the river (City of

62 Winnipeg, Water and Waste Department, 2020). Approximately 200 million liters of EF are

63 discharged per day (City of Winnipeg, Water and Waste Department, 2020).

64 The main indicator of biological contamination used in wastewater treatment screening is E. coli,

65 a fecal coliform bacterium (Hood et al., 1983). It is present in the gut of humans and warm- 
66 blooded animals, and widely used as the main indicator of fecal pollution during the wastewater

67 treatment process. Nevertheless, the use of only fecal bacteria indicator in wastewater excludes

68 other possible pathogen groups present, such as human enteric viruses. Targeting these viruses in

69 EF could be an alternative method to monitor the wastewater treatment process. Within this

70 context, Dutilh et al. (2014) targeted the DNA crAssphage genome in a human fecal sample.

71 With further bioinformatics testing, it was predicted that the crAssphage genome is highly

72 abundant, having been identified in $73 \%$ of human fecal metagenomes surveyed (Dutilh, et al.,

73 2014). The dynamics of crAssphage as human source marker has recently been explored in

74 fecally polluted environment (Ballesté et al., 2019; Wu et al., 2020). In terms of RNA viruses,

75 Pepper mild mottle virus (PMMV), a single-stranded RNA plant virus, has been identified highly

76 abundant in feces as a surrogate indicator to assess microbial quality for food, water and

77 wastewater (Zhang et al., 2006; Symonds et al., 2018).

78 In the present study, samples of RS, AS, EF, and biosolids/sludge cake (SC) from the NESTP

79 were collected (during fall 2019 and winter 2020) to investigate the potential of quantitating

80 human enteric viruses in wastewater samples as complementary indicators of contamination to

81 evaluate the processing stages of wastewater treatment. DNA enteric viruses in this study include

82 human Adenovirus (AdV) and cross-assembly phage (crAssphage), while RNA enteric viruses

83 include PMMV, Noroviruses (NoV) of the genogroups GI and GII, Astrovirus (AstV), Sapovirus

$84(\mathrm{SaV})$, and Rotavirus (RoV). We also studied the presence of a molecular marker for E. coli, the

85 uidA gene, in the samples collected from the NESTP. An overview of the workflow is illustrated 86 in Fig. 1. 
88 MATERIALS AND METHODS

89 Sample Collection. A liter of RS, AS, EF, and $1 \mathrm{~kg}$ of SC were collected from the NESTP

90 during each sampling event. Each sample was sealed in a 1-L sterile polyethylene container lined

91 with a sterile plastic bag. Samples were collected on October 22 ${ }^{\text {nd }}, 2019$ (Event 1) and November

$9228^{\text {th }}, 2019$ (Event 2 ) in the fall season. In the winter season, samples were collected on December

$9318^{\text {th }}, 2019$ (Event 3) and February $6^{\text {th }}, 2020$ (Event 4). SC samples were collected earlier in the

94 day during Events 3 and 4. All samples were kept at $4^{\circ} \mathrm{C}$ and processed within 24 hours of

95 collection.

96

97 Ultrafiltration of Wastewater Samples. Each wastewater treatment sample (RS, AS, and EF),

98 including Millipore Milli-Q water as a negative control, was first filtered via a funnel and

99 cheesecloth to remove any solid waste or debris. Next, $140 \mathrm{~mL}$ of each wastewater sample was

100 concentrated using an ultrafiltration method with Centricon Plus-70 filter units of $30 \mathrm{KDa}$

101 molecular-weight cutoff (Millipore Corporation, Billerica, MA, USA). The ultrafiltration process

102 used a sterile glass pipette, where $70 \mathrm{~mL}$ of each wastewater sample was added into their

103 correspondingly labeled sample filter cup pre-assembled with the filtrate collection cup. Each

104 assembly was then sealed with a cap. The Centricon Plus-70 assemblies were placed into a

105 swinging bucket rotor and centrifuged at $3000 \mathrm{xg}$ for 30 minutes at $20^{\circ} \mathrm{C}$. Subsequently, the

106 filtrate was discarded, and the remaining $70 \mathrm{~mL}$ of the samples was added into their

107 correspondingly labeled sample filter cup pre-assembled with the filtrate collection cup. Samples

108 were spun at the same speed and temperature for 45 minutes. After centrifugation, the sample

109 filter cup was separated from the filtrate collection cup. The concentration collection cup was

110 then turned upside down and placed on top of the sample filter cup. The device was carefully

Peer] reviewing PDF | (2021:08:64427:3:0:NEW 26 Jan 2022) 
111 inverted and placed into the centrifuge. Centricon Plus-70 filter units were centrifuged at $800 \times \mathrm{g}$

112 for 2 minutes at $20^{\circ} \mathrm{C}$. After this step, the concentrated sample was collected from the

113 concentration cup via a micropipette. The final volume was measured for each wastewater

114 sample. If needed, $10 \mathrm{mM}$ Tris-HCl, pH 8.5 buffer (Qiagen Sciences, Maryland, MD) was added

115 to the concentrate to make up a total volume of $250 \mu \mathrm{L}$. If the final volume of the concentrate

116 was over $250 \mu \mathrm{L}$, Tris buffer was not added. Aliquots containing $250 \mu \mathrm{L}$ were made and stored

117 at $4^{\circ} \mathrm{C}$ and processed within $24 \mathrm{~h}$.

118

119 Sludge Cake Preparation for Ultrafiltration. To remove cells and virus particles from the SC

120 samples, a $1 \mathrm{X}$ phosphate-buffered solution (PBS) with $0.15 \mathrm{M} \mathrm{NaCl}, 0.05 \%$ Tween-20, and $\mathrm{pH}$

1217.5 was used. Approximately $30 \mathrm{~g}$ of SC sample per sampling event (Events 3 and 4) was

122 collected and divided into six Falcon tubes for each event ( $\sim-6 \mathrm{~g}$ per tube). Approximately 30

$123 \mathrm{~mL}$ of PBS was added to each tube. The Falcon tubes filled with SC samples were homogenized

124 at constant agitation for 15 minutes at $2500 \mathrm{rpm}$ in a vortex mixer. These tubes were then

125 centrifuged at a speed of $4500 \mathrm{x} \mathrm{g}$ for 50 minutes. The supernatant from each tube was

126 subsequently recovered and transferred to a new sterile Falcon tube. For each sample event, 140

$127 \mathrm{~mL}$ of supernatant was used for ultrafiltration as described previously.

128

129 Nucleic Acid (DNA/RNA) Extraction and Fluorometric Assessment. Once the final volume

130 of concentrate was collected from each wastewater sample, the sample was pretreated with

131 InhibitEX buffer (Qiagen Sciences, Maryland, MD) as indicated by the manufacturer. Then,

132 QIAamp MinElute virus spin kit (Qiagen Sciences, Maryland, MD) was used to extract total

133 nucleic acids from each wastewater sample as per the manufacturer's instructions, which 
134 included the use of Qiagen Protease and carrier RNA (Qiagen Sciences, Maryland, MD).

135 Samples were eluted in $75 \mu \mathrm{L}$ of Buffer AVE (Qiagen Sciences, Maryland, MD), quantified, and

136 stored at $-80^{\circ} \mathrm{C}$ for downstream processes. The nucleic acid concentration and purity were

137 assessed using Qubit dsDNA high sensitivity and RNA assay kits in a Qubit 4 fluorometer

138 (Invitrogen, Carlsbad, CA, USA). Qubit results can be found in Supplementary Materials (Table $139 S 1)$.

140

141 Quantitative PCR Primers, Probes, and gBlocks Gene Fragments. Table 1 summarizes the

142 primers and probes used in this study. Forward and reverse primers listed in Table 1 were used in

143 the Primer-BLAST tool to extract gene target regions (Ye, et al., 2012). Extracted regions were

144 then uploaded to the Geneious software to verify oligonucleotide sequences associated to the 145 flanking regions and probe. The generated sequences were sent to Integrated DNA Technologies

146 (IDT, Inc., Coralville, Iowa, USA) to generate the desired gBlocks constructs. IDT manufactured 147 all the primers used for quantitative PCR (qPCR) and quantitative reverse transcription PCR 148 (RT-qPCR), as well as the probes Ast-P, Ring1a.2, and Ring 2.2 (Table 1). However, probes 149 SaV124TP, SaV5TP, Tampere NSP3, AdV-P, PMMV-Probe, and 056P1 were manufactured by 150 Life Technologies (Carlsbad, CA, USA).

151

152 Quantitative PCR Assays. Taqman Environmental Master Mix 2.0 (Life Technologies,

153 Carlsbad, CA, USA) was used for qPCR assays involving DNA enteric viruses and uidA.

154 Taqman Fast Virus 1-Step Master Mix (4X) (Life Technologies, Carlsbad, CA, USA) was used 155 for RNA enteric viruses via RT-qPCR. Each $10 \mu 1$ qPCR and RT-qPCR reaction contained 500 $156 \mathrm{nM}$ of each of the forward primer and the reverse primer and $250 \mathrm{nM}$ of its designated probe 157 when targeting both DNA and RNA viruses. Five $\mu \mathrm{l}$ of Environmental Master Mix was utilized 
158 in each qPCR reaction for targeting DNA viruses, while $2.5 \mu \mathrm{l}$ of 4x Fast Virus Master Mix was

159 used in each RT-qPCR reaction for targeting RNA viruses. The uidA qPCR reaction consisted of

$1605 \mu \mathrm{l}$ of Environmental Master Mix, $400 \mathrm{nM}$ of each primer, and $100 \mathrm{nM}$ of probe. All qPCR and

161 RT-qPCR reactions used $2 \mu$ of template.

162 Each qPCR and RT-qPCR reaction were performed in triplicate on an ABI QuantStudio 5 PCR

163 system (Applied Biosystems, Foster City, CA, USA). The DNA enteric viruses (AdV and

164 crAssphage) and uidA were subjected to the following conditions: $50.0^{\circ} \mathrm{C}$ for 2 minutes and

$16595.0^{\circ} \mathrm{C}$ for 10 minutes followed by 40 cycles of $95.0^{\circ} \mathrm{C}$ for 15 seconds and $60.0^{\circ} \mathrm{C}$ for 1 minute.

166 The RNA enteric viruses (SaV, RoV, AstV, GI and GII NoV, PMMV) were subjected to the

167 following conditions: $50.0^{\circ} \mathrm{C}$ for 5 minutes and $95.0^{\circ} \mathrm{C}$ for 20 seconds followed by 40 cycles of

$16895.0^{\circ} \mathrm{C}$ for 3 seconds and $60.0^{\circ} \mathrm{C}$ for 30 seconds. Raw qPCR and RT-qPCR output files can be

169 found on GitHub (https://git.io/J8VJ6).

170

171 Assessment of Ultrafiltration for Viral Recovery Efficiency. Armored RNA (Asuragen, Inc.,

172 Austin, TX, USA), an artificial virus packed with a 1000-bp single-stranded fragment and

173 encapsulated in a protein coat, was used to assess recovery efficiency of the ultrafiltration

174 method employed herein. We spiked in 16000 copies of Armored RNA into $7.5 \mathrm{~mL}$ of

175 representative RS, AS, and EF samples from the NESTP. For the SC sample, $1.25 \mathrm{~g}$ of solid SC

176 was dissolved in $7.5 \mathrm{~mL}$ of PBS $1 \mathrm{x}$ then homogenized by vortexing at $2500 \mathrm{rpm}$ for 15 minutes

177 and centrifuged at $4500 \mathrm{x}$ g for 50 minutes. The supernatant was transferred to a new Falcon tube

178 to be undergoing the same treatment as the RS, AS, and EF samples. The 7.5-mL MilliQ

179 negative control also spiked with 16000 copies of Armored RNA. These five samples were first

180 filtered through cheesecloth. $0.5 \mathrm{~mL}$ was aliquoted from each filtrate for subsequent assessment 
181 of recovery efficiency. The remaining volumes were subject to ultrafiltration using the Amicon

182 Ultra-15 Centrifugal Filter Unit (Millipore Corporation, Billerica, MA, USA). Again, $0.5 \mathrm{~mL}$ of

183 each flowthrough was stored for efficiency evaluation. Nucleic acid extraction of the retentate

184 was performed in a manner similar to that described above. The final elution volume was $30 \mu \mathrm{L}$.

185 Primers (381F: 5'- AGCCTGTCAATACCTGCACC-3' and 475R: 5'-

186 CACGCTTAGATCTCCGTGCT-3'), and probe (420P: 5' Cy5-

187 AGAGTATGAGAGGTCGACGA-TAO 3') were designed using Primer design tool of Geneious

188 Prime version 2021.1.1 (https://www.geneious.com) and targeted a 95-bp region within the

189 Armored RNA genome. This targeted 95-bp fragment was sent to Integrated DNA Technologies

190 (IDT, Inc., Coralville, Iowa) to synthetize a gBlock construct. Serial dilutions of this synthetic

191 fragment were used to generate standards and quantify gene copy numbers (GCNs) of Armored

192 RNA via RT-qPCR. DNA quantification using the same 95-bp fragment was also performed via

193 qPCR. Standards, samples, and non-template controls were run in triplicate.

194 Thermal cycling reactions were performed at $50^{\circ} \mathrm{C}$ for 5 minutes, followed by 45 cycles at $95^{\circ} \mathrm{C}$

195 for 10 seconds and $60^{\circ} \mathrm{C}$ for 30 seconds on a QuantStudio 5 Real-Time PCR System (Life

196 Technologies, Carlsbad, CA, USA). For RNA assays, each 10- $\mu$ l RT-qPCR mixture consisted of

$1972.5 \mu \mathrm{L}$ 4X TaqMan Fast Virus 1-Step Master Mix (Life Technologies, Carlsbad, CA, USA), 400

$198 \mathrm{nM}$ each primer, $200 \mathrm{nM}$ probe, and $2.5 \mu \mathrm{l}$ of template, as well as ultrapure DNAse/RNAse free

199 distilled water (Promega Corporation, Fitchburg, WI, USA). For DNA assays, $5.0 \mu \mathrm{L}$ Master

200 Mix was used.

201

202

Assessment of Gene Copy Numbers by Volume and Biomass. Gene copy numbers (GCNs)

203 were expressed in terms of sample (per mL or g of sample) and biomass (per ng of DNA or 
204 RNA). GCNs per mL of sample were calculated as previously described by Ritalahti et al.

205 (2006). When calculating GCNs per $\mathrm{mL}$ of sample, the final volume recovered after filtering 140

$206 \mathrm{~mL}$ of wastewater sample was used in the formula. For the SC samples, the mass of SC collected

207 was used in the formula to produce results in GCNs per $\mathrm{g}$ of sample.

208

209 Collection of Metadata for Sampling Events. To perform Principal Component Analysis

210 (PCA) and Spearman's rank correlation analysis for EF samples, metadata pertinent to the

211 sampling events was retrieved. Water quality parameters obtained from the NESTP were

212 combined with their October 2019 monitoring data (City of Winnipeg, Water and Waste

213 Department, 2019) to complete some of the missing fields. For each value not found in either

214 document, data interpolation was performed by taking an average of the corresponding values for

215 the days before and after the sampling event. In addition, the Government of Canada's historical

216 weather database was utilized to obtain the mean temperature on the sampling dates and the total

217 precipitation over three days before each sampling event (hereafter referred to as "precipitation")

218 (Environment and Climate Change Canada, 2021). The values for all parameters were

219 transformed using $\log _{10}$, except for precipitation due to the presence of zero values. These

220 variables were used with $\log _{10}$-transformed GCNs per mL sample for AdV, crAssphage, PMMV,

221 and uidA (targets with quantifiable qPCR and RT-qPCR readings for all replicates across all

222 events) as input for downstream analyses (PCA and Spearman's rank correlation analysis).

223

224 Data Handling, Statistical Analysis, and Data Visualization. Various applications were

225 employed to process data at different steps of the pipeline. Input data, such as output from the

226 quantitative PCR instrument, was subjected to manual formatting and cleaning in Microsoft 
227 Excel, which was also used to calculate GCNs per $\mathrm{mL}$ or g sample and per ng nucleic acid.

228 GCNs and metadata were transformed using $\log _{10}$ function for analysis. GCNs across sampling

229 events were pooled, and then comparisons were conducted across treatment.

230 R (R Core Team, 2021) and its integrated development environment RStudio (RStudio Team,

231 2021) as well as Statistical Analysis System (SAS, version 9.4 for Windows) were utilized to

232 further process the data and perform statistical analyses and output visualizations. These

233 operations included general linear models and multiple comparison procedures using Tukey's

234 tests, PCA (corresponding biplots were created using the package ggbiplot version $0.55(\mathrm{Vu}$,

235 2011)), and Spearman's correlation matrix using the package Hmisc version 4.5-0 (Harrell Jr.,

236 2021). The package reshape2 version 1.4 .4 (Wickham, 2020) was used to reformat these

237 correlation matrices to enhance compatibility with other data-handling tools. Information about

238 other packages is provided in Supplementary Materials (Table S2). The R script used for analysis

239 can be found on GitHub (https://git.io/J8VU1). Additional t-tests were conducted to compare

240 water quality parameters between influent (RS) and discharges (EF).

241 Another software involved in data visualization was Tableau. Specifically, it was used to

242 generate boxplots for GCNs per $\mathrm{mL}$ or g sample and per ng nucleic acid, as well as the heatmap

243 representing the above-mentioned Spearman correlation matrix.

244 For all tests, a p-value of 0.05 was assumed to be the minimum level of significance.

\section{RESULTS}

247 From our assessment of the sample processing method used in this study, the recovery

248 efficiencies of Armored RNA as measured by RT-qPCR were between 14.03\% and 15.94\% for

249 RS, $2.63-4.36 \%$ for AS, $12.36-18.74 \%$ for EF, and 2.40-5.45\% for SC. Meanwhile, DNA 
250 recovery efficiencies were $32.48-40.87 \%$ (RS), $20.96-45.22 \%(\mathrm{AS}), 14.14-20.15 \%$ (EF), and $251 \quad 23.41-68.42 \%(\mathrm{SC})$.

252 The GCN values for the DNA and RNA viruses and uidA were transformed into $\log _{10}$ form.

253 These values were run through a general linear model Tukey-Kramer analysis, and the means of 254 each wastewater processing stage for each target were analyzed. The GCNs were expressed in 255 terms of volume ( $\mathrm{mL}$ ) or weight ( $\mathrm{g}$ ) of sample and biomass (ng of nucleic acids). The result for 256 the GCN representing triplicate values from the corresponding sampling event was visualized as 257 a circle in the box plots. We followed cut-off $\mathrm{Ct}$ values established by the Molecular 258 Microbiology \& Genomics Team at the British Columbia Centre for Disease Control (2017a, 259 2017b). With these values, the presence of DNA and RNA viral gene copies and uidA in the 260 Milli-Q water (negative control) samples across all Events 1-4 were determined to be negative.

261 The boxplots in Figs. 2-6 indicate the minimum, first quartile, median, third quartile, and 262 maximum of the GCNs of each wastewater treatment sample across all events.

263 Overall, the average GCNs of the DNA and RNA enteric viruses assessed in RS, EF and SC 264 were significantly and consistently higher $(\mathrm{p}<0.05)$ compared to AS in terms of both volume and 265 biomass (Fig. 2-3, S1 and S2). Average values of AdV ranged from 6.5 (AS) to 370.3 (SC)

266 GCNs per ml or $\mathrm{g}$ of sample (Fig. 2A), while that RS and EF had on average 33.1 and 38.5 267 GCNs per ng DNA (Fig. 2B). Moreover, crAssphage ranged from 264 (AS) to 65,388 (SC) 268 GCNs per ml or g of sample (Fig. 2C). Except for AS, crAssphage values in terms of biomass 269 were unaltered across wastewater processes (Fig. 2D). In terms of RNA viruses, PMMV were 270 observed in higher values ( $\mathrm{p}$-value $\leq 0.0001)$ in SC compared to other treatments (Fig. 3).

271 Average values for $\mathrm{SC}$ were $6,478.1$ copies per $\mathrm{g}$ and 189.2 copies per ng of sample. Similar to 272 GCNs of AdV and crAssphage, lower values were observed in AS. On the other hand, values for 
273 uidA per volume were not significant ( $p$-value $\geq 0.3716$ ), we observed in higher and significant

$274(\mathrm{p} \leq 0.0273)$ numbers of uidA per biomass in RS and EF compared to SC (Fig. 4). No other

275 significant differences were detected for uidA. For all the aforementioned targets, there was a

276 relatively higher number of gene copies observed in the EF across all events compared to AS

277 samples.

278 NoV GI and GII were also targets for our study. Boxplots of their GCNs across the different

279 wastewater stages and events 1-4 can be found in Supplementary Materials (Fig. S1). Norovirus

280 GI was below RT-qPCR detection limits for all samples (RS, AS, and EF) during the events 1

281 and 2 (Fall season). Values were only detected during events 3 and 4 (Winter season). When

282 detected NoV GI GCNs were higher (p-value < 0.0001) in SC, EF and RS compared to AS.

283 Values ranged between 0.4 (AS) to 51.8 (SC) per ml or g of sample, while that in terms of

284 biomass NoV GI GCNs were observed between 0.05 (AS) and 2.1 (EF). In addition, NoV GII

285 GCNs for all samples collected in Event 2 and AS samples in Events 3 and 4 (Winter season)

286 were also below the detection limits (Fig. S1). Among the quantifiable samples, statistically

287 significant GCN differences in terms of volume/mass and biomass were calculated for the pairs

288 of AS-EF (p-values were 0.0129 and 0.0117 , respectively), AS-RS ( $\mathrm{p}$-value=0.0223 per volume),

289 and AS-SC (p-value $<0.0001$ for both). No other significant differences were detected among

290 treatments for GCNs of NoV GII.

291 RoV gene copies across the various wastewater treatment stages from Event 1 to 4 were also

292 examined. The boxplots illustrating these results in terms of both sample and biomass can be

293 found in the Supplementary Materials (Fig. S2). RoV GCNs were only detected for wastewater

294 samples collected during Events 3 and 4. Higher values per volume and biomass were detected in

295 SC compared to the other treatments. RoV values ranged from 0.9 (AS) to 26.8 (SC) and 0.08 
296 (AS) to 0.8 in terms of volume/mass and biomass, respectively. RoV GCNs were higher (0.0186)

297 in EF per volume and biomass compared to AS. Looking at the EF-SC pair, the mean GCNs 298 differed significantly in terms of volume/mass ( $p$-value $<0.0001)$ but not biomass ( $p$-value $=$ 299 0.8510). No other significant differences were detected for RoV per volume/mass or biomass.

300 In the present study, there was no detection of gene copies for AstV and SaV (Sav1, Sav124, and 301 Sav5) in any of the wastewater samples across all events. In addition, to eliminate the possibility 302 of inhibitors or contaminants such as humic acids, additional qPCR and RT-qPCR tests using 303 bovine serum albumin (data not shown) were conducted with environmental samples (including 304 AS). No significant differences were observed between samples with and without the enzyme. 305 To investigate any potential relationship between collected data for EF samples, PCA was 306 performed with $\log _{10}$-transformed variables. We found that three components (PC1, PC2, and 307 PC3) explained $99.14 \%$ of the variance between variables. A summary of the weight of 308 components is included in the Supplementary Materials (Table S3). PC1 and PC2 were used to 309 create the biplot in Fig. 5. Biplots for PC1 versus PC3 (Fig. S3) and PC2 versus PC3 (Fig. S4). 310 Water quality parameters associated to UV-final effluents and used for PCA are summarized in 311 Table 2. Physico-chemical and biological wastewater parameters (metadata) are also included in 312 the Supplementary Materials. Water quality parameters available for RS and EF were also 313 compared. Organic pollutants in EF from the NESTP were significantly reduced for BOD (p314 value $<0.0001)$, COD (p-value $<0.0001)$, sCOD (p-value $=0.0046)$, TOC (p-value $<0.0001)$, 315 TP $(p$-value $=0.0069)$, TS $(p$-value $=0.0223)$, and TSS $(p$-value $<0.0001)$. No significant 316 differences were observed between $\mathrm{RS}$ and $\mathrm{EF}$ for $\mathrm{NH}_{4} \mathrm{~N}$ ( $\mathrm{p}$-value 0.5006), and TN (p-value $3170.3312)$.

318 Overall, based on the biplot of PC1 and PC2, samples from the four events were distinct from 
319 one another, as point clusters of the four events can be seen occupying different quadrants. PC1,

320 explaining $54.9 \%$ of the observed variance, received a notable and positive contribution from

321 COD, cBOD, BOD, and TOC. Strongly negative contributors to PC1 were mean temperature,

322 grab filtered UVT, $\mathrm{NO}_{\mathrm{x}}-\mathrm{N}$, and TS. These observations were supported by subsequent

323 Spearman's rank correlation analysis (Fig. 6), as COD, cBOD, BOD, and TOC demonstrated

324 strongly positive correlations with one another (rho ranging between 0.8000 and 0.9487 ) (p-

325 value $<0.005$ ) and strongly negative correlations with mean temperature, grab filtered UVT,

$326 \mathrm{NO}_{\mathrm{x}}-\mathrm{N}$, and TS (rho ranging between -1.000 and -0.8000) (p-value $\left.<0.005\right)$. PC2 explained

$32731.9 \%$ of the variance between sampling events and showed a strong contribution from

328 crAssphage, uidA, and grab temperature. This observation was also supported by the Spearman's

329 rank correlation analysis showing these variables having strongly positive correlation with one

330 another (rho ranging between 0.7169 and 0.9218 ) (p-value $<0.0100$ ). Additionally, in the biplot,

331 the axes representing $E$. coli and fecal coliform specifically pointed towards the same quadrant,

332 which was reflected in their moderately positive Spearman's coefficient $(0.6325)$ (p-value $=$

333 0.0273). However, it is worth noting that uidA and E. coli exhibited a moderately weak negative

334 correlation $(\mathrm{rho}=-0.3073)$, although it was not statistically significant $(\mathrm{p}$-value $=0.3313)$. The

335 two parameters with the strongest contribution against PC2 were grab pH and turbidity, which

336 was illustrated by the strongly positive Spearman's coefficient heatmap (rho $=0.8000)(p$-value

$337=0.0018)$.

\section{DISCUSSION}

340 The ultrafiltration method used in this study was assessed and the recovery efficiencies among

341 all samples for Armored RNA were estimated to be between 2.40-18.74\% for RNA. This range 
342 was comparable to other methods to concentrate viral particles such as JumboSep (13.38\% \pm

$3439.11 \%)$ or skimmed milk flocculation $(15.27 \% \pm 3.32 \%)$, spiked-in wastewater samples, and

344 using Armored RNA as internal control (Yanaç et al., 2021). Viral particles may have been

345 sorbed to biosolids present in wastewater samples, which were filtered out during the processing

346 stage. In this context, matrix has a significant effect for recovery of viral particles. When

347 compared to other environmental matrices such as surface water samples, recovery efficiency is

348 higher using ultrafiltration (tangential flow filtration) $(32.6 \% \pm 11.81 \%)$ and skimmed milk

349 flocculation $(42.64 \% \pm 15.12 \%)$ (Francis and Uyaguari, unpublished results). Water with high

350 turbidity and amounts of suspended solids tend to saturate filters and impact the recovery of viral

351 particles (Aslan et al., 2011; Karim et al., 2009; Uyaguari-Diaz, et al., 2016). Additionally, the

352 flow-through from ultrafiltration is another potential source of lost nucleic acid.

353 The GCNs were expressed in terms of biomass and volume (except for SC, which was expressed

354 in g of sample). The higher abundance and more stable signal over time of GCNs of AdV and

355 crAssphage (Fig. 2) as well as PMMV (Fig. 3) relative to the results of other assays make these

356 target more representative for conducting comparisons with E. coli. This persistent presence is

357 consistent with various longitudinal studies previously performed (Ballesté, et al., 2019; Farkas,

358 et al., 2018; Farkas, et al., 2019; Hamza et al., 2019; Nour, et al., 2021; Schmitz et al., 2016;

359 Tandukar et al., 2020; Worley-Morse et al., 2019; Wu et al., 2020).

360 A reduction of AdV, crAssphage, PMMV, and uidA GCNs was observed consistently in AS

361 samples (Figs. 2-4). This could be a result of virus particles and bacterial cells being sorbed to

362 larger fractions of organic matter that had been filtered by cheesecloth early in the sample-

363 handling process or retained in the filtration devices as previously described. It is important to

364 mention that samples were collected within a 2-hour period from RS $\rightarrow \mathrm{AS} \rightarrow \mathrm{EF}$ consecutively 
365 within each sampling event. The higher GCNs of viruses and E. coli observed in the EF may be

366 associated with the hydraulic retention time (12 hours) in the facility and may not reflect

367 wastewater treatment profiles at the time of collection. In other words, the EF samples may not

368 have been the corresponding RS samples collected earlier. The ideal situation would have seen

369 the former being collected 12 hours after the latter. It is best that similar logistical issues be

370 accounted for in future studies. Other variables to consider are the overflow of sewage from

371 rainy events and fluctuations in mixed liquor-suspended solids (Pérez et al., 2019). In our study,

372 there were $4.6 \mathrm{~mm}$ of precipitation for Event 1, which may have affected the results. In the PCA

373 analysis (Fig. 5), the vector for precipitation sharply denotes data points representing Event 1,

374 indicating a possible relationship. Precipitation was also found to have positive correlations with

375 grab flow $($ rho $=0.7746)$ and raw flow $($ rho = 0.7746) $($ Fig. 6). Nonetheless, further studies

376 and/or more replications are needed to corroborate the potential link between precipitation and

377 microbial counts.

378 Moreover, the duration of anaerobic sludge digestion is 25 days (City of Winnipeg, Water and

379 Waste Department, 2020). In this context, GCNs of uidA in the SC were reduced by anaerobic

380 digestion (Fig. 4). This may explain why the gene copies of uidA in terms of biomass were lower

381 in SC compared to RS and EF ( $\mathrm{p}$-value $<0.0273$ ), but not when compared to AS ( $\mathrm{p}$-value $=$

382 0.0705). The average gene copies across all wastewater stages (RS, AS, and EF) for uidA were

383 not significantly different in terms of both volume and biomass. When compared to uidA, enteric

384 viruses were found to be at least one order of magnitude more abundant than the E. coli marker.

385 Other studies have reported uidA in RS at copy numbers between 2 to 4 orders of magnitude

386 higher that in our report (Jikumaru, et al., 2020; Mbanga et al., 2020). In a related study

387 conducted in the NESTP, we observed the same orders of magnitude for uidA gene marker 
388 across wastewater treatments (Jankowski et al., 2022) as the ones reported here. Although we 389 acknowledge some sample may have been lost during the cheesecloth pre-filtration step, the 390 same order of magnitude observed in both studies reflects true positive values for uidA across 391 wastewater treatment processes.

392 GCNs of crAssphage in terms of biomass in SC were significantly higher than AS (p-value $=$ 393 0.0123) (Fig. 2). For PMMV, SC samples had significantly more GCNs in terms of volume/mass 394 and biomass than samples from other parts of the wastewater treatment process (p-value $\leq$ 395 0.0030) (Fig. 3). Since SC is the by-product of RS and AS using anaerobic digestion, this may 396 indicate that the presence of crAssphage and PMMV was lower in the wastewater being treated 397 in the AS, but higher in the solids. On the other hand, GCNs of AdV in terms of biomass were 398 not significantly different between the AS and SC samples (Fig. 2B). Meanwhile, plant viruses 399 such as PMMV remain more stable (in terms of biomass) during these digestion processes 400 (Jumat, et al., 2017).

401 The higher presence ( $\mathrm{p}$-value $<0.0001$ ) of RoV gene copies in the EF and SC in terms of 402 volume/mass and biomass during the winter season (Fig. S2 and Table 2) may indicate a higher 403 risk of transmission during cold seasons (Atabakhsh et al. 2020), since a greater presence of RoV 404 in EF and SC has been previously found during the colder months of the year (Li, et al., 2011) 405 and little decay occurs at the desiccation step (Sánchez \& Bosch, 2016).

406 The negative results of $\mathrm{SaV}$ (Sav1, Sav124, and Sav5) across all wastewater treatment stages 407 during the fall and winter season are consistent with Varela et al. (2018) where samples were 408 retrieved from a wastewater treatment plant in Tunisia. Their results did not support the general 409 belief that the peak of detection of $\mathrm{SaV}$ occurs during the cold and rainy months of the year. 
410 However, quantitative detection of $\mathrm{SaV}$ in wastewater and river water in Japan showed an

411 increased concentration of $\mathrm{SaV}$ in influents between winter and spring (December to May), but a

412 decrease in $\mathrm{SaV}$ concentration during the summer and autumn months (July to October)

413 (Haramoto et al., 2008). Yet another pattern of SaV presence was reported in France, as Sima et

414 al. (2011) found the virus to be readily detected in influents but had no clear variations in

415 numbers over the 9-month (October to June) duration of the study. Similarly, seasonal

416 differences in $\mathrm{SaV}$ concentrations were not statistically significant in a 3-year study conducted

417 by Song et al. (2021) in China between 2017 and 2019. As a result, there are other factors that

418 can influence wastewater $\mathrm{SaV}$ concentrations. For example, it has been hypothesized that

419 isoelectric point could affect how viruses and their different strains behave in bioreactors (Miura

420 et al., 2015). Monitoring over a time period longer than our current study would likely shed more

421 insight into the seasonal variation in the presence of $\mathrm{SaV}$ in wastewater.

422 The gene copies of NoV GI and GII were below the detection limit in many of the AS samples

423 (in terms of both volume and biomass), but still relatively abundant in the other samples (Fig.

424 S1). A possible explanation for the greatly reduced viral GCNs in AS samples is the high

425 efficiency with which NoV GI and GII are removed, a notion supported by literature (Ibrahim et

426 al., 2020; Kitajima et al., 2014; Schmitz et al., 2016). Furthermore, considering the observation

427 that these viruses were found in abundance in SC samples, another contributing factor could be

428 limitations in the sample collection process, which might not have adequately retrieved the slurry

429 part of the sludge where the viruses are found in greater numbers as they might have sorbed to

430 the larger fractions of the sludge solids. The relative abundance of NoV GI and GII gene copies

431 in RS, EF, and SC during the colder months (December and February) and the absence of NoV

432 GII in RS in November may be due to seasonal variability including intermittences (Guix et al., 
433 2002; Pérez et al, 2019; Sánchez and Bosch, 2016). In this context, the presence of NoV GI and

434 GII gene copies in RS during Events 3 and 4 (December and February) is consistent with a study

435 conducted by Flannery et al. (2012), in which the concentration of NoV GI and GII gene copies

436 in the influents of a wastewater treatment plant were significantly higher during the winter

437 months (January to March). During colder months, we observed mean (ambient) temperatures

438 averaged $-17.05^{\circ} \mathrm{C}$ (Table 2$)$. This seasonal trend is also reflected colloquially through the

439 virus's sobriquet, the winter vomiting bug (Farkas, et al., 2021). Overall, GCNs of NoV GI and

440 GII did not seem to be reduced by the wastewater treatment process (Fig. S1).

441 High numbers of AstV gene copies (per liter) in sewage samples from the Greater Cairo area in

442 Egypt were observed at the end of autumn (daily mean temperatures ranged from $10.8^{\circ} \mathrm{C}$ to 22.8

$443^{\circ} \mathrm{C}$ ) and during the winter months (daily mean temperatures ranged from $6.8^{\circ} \mathrm{C}$ to $\left.17.0^{\circ} \mathrm{C}\right)(\mathrm{El}-$

444 Senousy et al., 2007; Weather Spark, 2022), but the AstV concentrations tended to decrease as

445 temperatures increased. These results are different from our findings where there was no

446 detection of AstV in any of the wastewater treatment stages across all events. Mean (ambient)

447 and grab sample average temperatures during our study-period were $-9.5^{\circ} \mathrm{C}$ (range $2.7^{\circ} \mathrm{C}$ to -

$448 \quad 17.1^{\circ} \mathrm{C}$ ) and $13.6^{\circ} \mathrm{C}$ (range $12.7^{\circ} \mathrm{C}$ to $14.1^{\circ} \mathrm{C}$ ), respectively (Supplementary Materials and

449 Table 2). These results may be due to seasonal variability (Pérez et al., 2019) as well as reflect

450 the pattern of infection within the community under study (Corpuz et al., 2020).

451 Grab filtered UVT being inversely correlated with COD, cBOD, BOD, and TOC is consistent

452 with the widespread use of UV radiation to regulate microbial growth in a variety of medium,

453 including water (Raeiszadeh \& Adeli, 2020). Furthermore, it had been suggested that UV is an

454 important influence to the survival of pathogens in wastewater environments, especially in cold

455 weather conditions, such as those found in Manitoba during the surveying period (Murphy, 
456 2017). The NESTP uses UV as disinfection treatment and significantly reduces most organic

457 pollutants (RS vs EF). In the present study, we observed an incomplete removal of nitrogen (TN

458 and $\mathrm{NH}_{4}-\mathrm{N}$ ). Excess of these nutrients is associated to efficiency of the activated sludge process

459 and discharges can be toxic for aquatic organisms and/or cause algal blooms (Templeton \&

460 Butler, 2011; Chahal et al., 2016). Moreover, virus-mediated transfer of nitrogen can occur from

461 heterotrophic bacteria such as the pool of microorganisms present in AS to primary producers in 462 aquatic environments (Shelford \& Suttle, 2018; Chen et al., 2021). Further studies are needed to 463 evaluate the survival of enteric viruses in these reservoirs by using modification to the biological 464 treatment, the disinfection process and/or physical methods (i.e., filtration methods). Some of 465 these modifications may include fixed bed reactors (Sizirici \& Yildiz, 2020), biofilm systems 466 such as membrane bioreactors, biofilters, biofiltration, and carriers (Zhao et al., 2019). Other 467 disinfection processes include the use of chlorine (liquid sodium hypochlorite solution, solid 468 calcium hypochlorite) or newer methods such as ozone (Mezzanotte et al., 2007; Abou-Elela et 469 al., 2012; Collivignarelli et al., 2018). Although microfiltration and ultrafiltration can be used to 470 reduce bacterial and protist pathogens, and enteric viruses (Chahal et al., 2016), membrane

471 foulants and fouling mechanisms occur in WWTP effluents (Nguyen et al., 2010).

472 There is a possibility that viral GCNs quantified in the EF may represent an overestimation of the 473 actual number of infectious viral particles since quantitative PCR detects both infective and non474 infective agents and UV treatment influences viral viability (Lizasoain et al., 2017). Thus, the 475 interpretation of these results must be performed with caution. Future studies could incorporate 476 culturable assays for a more complete and accurate evaluation as well as longer time series. On 477 the other hand, it is also possible that the non-enveloped enteric viruses (Corpuz, et al., 2020) 478 studied here survived the wastewater treatment process. Non-enveloped viruses are more 
479 resilient than their enveloped counterparts in numerous environmental conditions and water

480 treatment processes (La Rosa et al., 2020). This is because of the latter group's envelope, which

481 contains receptors needed for infection; if the envelope is lysed, infection is not possible (La

482 Rosa et al., 2020). Various publications have noted the resilience of non-enveloped viruses after

483 wastewater treatment (Adefisoye et al., 2016; Campos \& Lees, 2014; Farkas, et al., 2019;

484 Fitzgerald, 2015; Fong et al., 2010; Li, et al., 2021; Prevost, et al., 2015; Ruggeri, et al., 2015;

485 Varela, et al., 2018). In this context, we have consistently detected GCNs of AdV, crAssphage, 486 and PMMV in environmental surface waters receiving discharges from the NESTP, two other

487 WWTPs, and other areas radiating away from the WWTPs within the City of Winnipeg (Francis 488 and Uyaguari, unpublished data). Therefore, despite potential factors affecting interpretation, our 489 results still reflect the presence of several non-enveloped enteric viruses in EF and SC samples 490 with reasonable quantitative accuracy. While it is undeniable the key role that WWTPs have 491 played in reducing nutrient loading and maintain water quality, they are not designed to remove 492 all microbes, especially smaller fractions such as viruses, genetic material or micropollutants. In 493 this aspect, unproperly treated effluents or mismanagement of SC, often employed as fertilizers, 494 may represent a route for microbes including pathogens and their genetic material to be 495 transported into downstream waterways or introduced into other settings (i.e., 496 urban $\rightarrow$ agricultural, urban $\rightarrow$ rural).

\section{CONCLUSION}

499 Our study's primary goal was to identify human enteric viruses with the potential to become 500 alternative indicators of fecal pollution. Towards that end, we found AdV, crAssphage, and

501 PMMV as more stable viral indicators of water quality due to their quantifiability illustrated in 
502 this investigation and the literature. RNA viruses such as NoV GI and GII, and Rotavirus were

503 detected during colder months, while AstV and $\mathrm{SaV}$ could not be detected in any of the samples.

504 Regular monitoring of these organisms can be useful complements to current methods for

505 assessing wastewater treatment processes including seasonal viruses. Wastewater surveillance of

506 SARS-CoV-2 during the current pandemic has demonstrated the utility of early warning tools.

507 Such vigilance could be a helpful tool to assist public health efforts in the event of a viral

508 outbreak.

509 Our study indicated that enteric viruses may have survived the wastewater treatment process and

510 viral-like particles are possibly being released into the aquatic environment. Therefore, in

511 addition to such methods as UV radiation (which is currently used in the NESTP and was shown

512 in our study to be inversely correlated with biological parameters), we also suggest that WWTPs

513 consider implementing modifications and/or additions (disinfection processes) to their workflow

514 to reduce the number of viral particles being released into the aquatic environment.

515

516 ABBREVIATIONS

517 AdV: Adenovirus

518 AS: activated sludge

519 AstV: Astrovirus

520 BOD: biochemical oxygen demand

521 cBOD: carbonaceous biochemical oxygen demand

522 COD: chemical oxygen demand

523 EF: effluents

524 GCN: gene copy number 
525 NESTP: North End Sewage Treatment Plant

$526 \mathbf{N H}_{4}-\mathrm{N}$ : ammonium-nitrogen

527 NoV: Norovirus

$528 \mathrm{NO}_{\mathbf{x}}-\mathbf{N}$ : nitrogen oxides - nitrogen

529 PCA: Principal Component Analysis

530 PMMV: Pepper mild mottle virus

$531 \mathbf{P O}_{4}-\mathbf{P}:$ orthophosphate as phosphorus

532 RoV: Rotavirus

533 RS: raw sewage

534 qPCR: quantitative PCR

535 RT-qPCR: quantitative reverse transcription PCR

536 SaV: Sapovirus

537 SC: sludge cake

538 sCOD: soluble chemical oxygen demand

539 TN: total nitrogen

540 TOC: total organic carbon

541 TP: total phosphorus

542 TS: total solids

543 TSS: total suspended solids

544 uidA: $\beta$-d-glucuronidase gene

545 WWTP: wastewater treatment plant 


\section{AUTHOR CONTRIBUTIONS}

547 AG performed the experiments, analyzed the data, prepared the figures and tables, and wrote and

548 reviewed the drafts of the manuscript.

549 TL performed the validation experiments, analyzed the data, prepared the figures and tables, and 550 wrote and reviewed the drafts of the manuscript.

551 PJ performed the experiments, prepared table and reviewed the drafts of the manuscript.

552 KY performed the validation experiments and reviewed the drafts of the manuscript.

553 QY contributed the analysis tools and reviewed the drafts of the manuscript.

554 MUD designed the experiments, provided lead guidance during the experiments and analyses, 555 contributed the analysis tools, analyzed the data, prepared the figures and tables, and wrote and 556 reviewed the drafts of the manuscript.

557 All authors read and approved of the final manuscript.

\section{ACKNOWLEDGEMENTS}

559 Special thanks to the City of Winnipeg and Palwinder Singh, graduate student, Department of 560 Civil Engineering at the University of Manitoba (UoM) for sample collection. Research start-up 561 funds grant No. 322388 were assigned to Miguel Uyaguari-Diaz at the UoM. We acknowledge 562 The Faculty of Science, UoM, collaborative grant No. 322788 (Drs. Uyaguari and Yuan).

563 This research was conducted at the University of Manitoba. We would like to acknowledge that 564 the University of Manitoba campuses are located on original lands of Anishinaabeg, Cree, Oji565 Cree, Dakota, and Dene peoples, and on the homeland of the Métis Nation. 


\section{REFERENCES}

568 Abou-Elela, S. I., El-Sayed, M. M. H., El-Gendy, A. S., \& Abou-Taleb, E. M. (October 2012).

569

570 Comparative study of disinfection of secondary treated wastewater using chlorine, UV

571

572

Adefisoye, M. A., Nwodo, U. U., Green, E., \& Okoh, A. I. (2016). Quantitative PCR Detection

573 and Characterisation of Human Adenovirus, Rotavirus and Hepatitis A Virus in Discharged Effluents of Two Wastewater Treatment Facilities in the Eastern Cape, South

574 Africa. Food and Environmental Virology, 8, 262-274. doi:10.1007/s12560-016-9246-4

575

Aslan, A., Xagoraraki, I., Simmons, F., Rose, J., \& Dorevitch, S. (2011, August 19). Occurrence 576

577

578

579

580

581

582 of adenovirus and other enteric viruses in limited-contact freshwater recreational areas and bathing waters. Journal of Applied Microbiology, 111(5), 1250-1261. doi:10.1111/j.1365-2672.2011.05130.x

Ballesté, E., Pascual-Benito, M., Martín-Díaz, J., Blanch, A. R., Lucena, F., Muniesa, M., Jofre, J., \& García-Aljaro, C. (2019, May 15). Dynamics of crAssphage as a human source tracking marker in potentially faecally polluted environments. Water Research, 155, 233244. doi:10.1016/j.watres.2019.02.042

Campos, C. J., \& Lees, D. N. (2014, June). Environmental Transmission of Human Noroviruses

Chahal, C., van den Akker, B., Young, F., Franco, C., Blackbeard, J., \& Monis, P. (2016, 587 September 15). Pathogen and Particle Associations in Wastewater: Significance and in Shellfish Waters. Applied and Environmental Microbiology, 80(12), 3552-3561. Implications for Treatment and Disinfection Processes. Advances in Applied Microbiology, Vol 97, 63-119. doi:10.1016/bs.aambs.2016.08.001. 
590 Chen, Y., Wang, Y., Paez-Espino, D., Polz, M. F., \& Zhang, T. (2021, September 13).

591 Prokaryotic viruses impact functional microorganisms in nutrient removal and carbon 592 cycle in wastewater treatment plants. Nature Communications, 12(1), 5398.

593 doi:10.1038/s41467-021-25678-1

594 City of Winnipeg, Water and Waste Department. (2019, October). North End Water Pollution 595

596 Control Centre Monitoring Data. Winnipeg, Manitoba, Canada. Retrieved July 21, 2021, from

597

598 https://www.winnipeg.ca/waterandwaste/pdfs/sewage/ComplianceReporting/2019/oct/ne wpcc.pdf

599 City of Winnipeg, Water and Waste Department. (2020, October 8). Sewage Treatment Plants.

600 Retrieved July 21, 2021, from City of Winnipeg:

601

602 https://www.winnipeg.ca/waterandwaste/sewage/treatmentPlant/default.stm\#tab-north-

603 Collivignarelli, M.C., Abbà, A., Benigna, I., Sorlini, S., \& Torretta, V. (2018). Overview of the 604 Main Disinfection Processes for Wastewater and Drinking Water Treatment

605 Plants. Sustainability, 10, 86. https://doi.org/10.3390/su10010086.

606 Comber, S. D., Gardner, M. J., \& Ellor, B. (2020, September). Seasonal variation of contaminant 607 concentrations in wastewater treatment works effluents and river waters. Environmental 608 Technology, 41(21), 2716-2730. doi:10.1080/09593330.2019.1579872

Corpuz, M. V., Buonerba, A., Vigliotta, G., Zarra, T., Ballesteros Jr, F., Campiglia, P., .. .

610 Naddeo, V. (2020, November 25). Viruses in wastewater: occurrence, abundance and detection methods. Science of the Total Environment, 745. doi:10.1016/j.scitotenv.2020.140910 
613 Dutilh, B. E., Cassman, N., McNair, K., Sanchez, S. E., Silva, G. G., Boling, L., .. . Edwards, R.

614 A. (2014). A highly abundant bacteriophage discovered in the unknown sequences of

615 human faecal metagenomes. Nature Communications, 5(4498), 1-11.

616 doi:10.1038/ncomms5498

617 El-Senousy, W. M., Guix, S., Abid, I., Pintó, R. M., \& Bosch, A. (2007, January). Removal of

618

619 astrovirus from water and sewage treatment plants, evaluated by a competitive reverse transcription-PCR. Applied and Environmental Microbiology, 73(1), 164-7.

620 doi:10.1128/AEM.01748-06

621 Environment and Climate Change Canada. (2021). Historical Data. Retrieved July 21, 2021, 622 from Government of Canada:

623 https://climate.weather.gc.ca/historical_data/search_historic_data_e.html

624 Farkas, K., Adriaenssens, E. M., Walker, D. I., McDonald, J. E., Malham, S. K., \& Jones, D. L. 625 (2019, June). Critical Evaluation of CrAssphage as a Molecular Marker for HumanDerived Wastewater Contamination in the Aquatic Environment. Food and Environmental Virology, 11(2), 113-119. doi:10.1007/s12560-019-09369-1

Farkas, K., Green, E., Rigby, D., Cross, P., Tyrrel, S., Malham, S. K., \& Jones, D. L. (2021, May 27). Investigating awareness, fear and control associated with norovirus and other pathogens and pollutants using best-worst scaling. Scientific Reports, 11 . D. L. (2018, November). Seasonal and diurnal surveillance of treated and untreated wastewater for human enteric viruses. Environmental Science and Pollution Research, 25(33), 33391-33401. doi:10.1007/s11356-018-3261-y 
635 Fitzgerald, A. (2015). Review of Approaches for Establishing Exclusion Zones for Shellfish

636

637

638

639

640

641

642

643

644

645

646

647

648

649

650

651

652

653

654

655

656

657

Harvesting around Sewage Discharge Points - Desk Study to Inform Consideration of the Possible Introduction of Exclusion Zones as a Control for Norovirus in Oysters. Technical Report, Aquatic Water Services Ltd. Retrieved July 26, 2021, from https://webarchive.nationalarchives.gov.uk/20150418173120/http://www.food.gov.uk/sit es/default/files/Exclusion\%20Zones\%20Project\%20FS513404\%20\%20Technical\%20Report\%20FINAL.pdf

Fong, T.-T., Phanikumar, M. S., Xagoraraki, I., \& Rose, J. B. (2010, February). Quantitative detection of human adenoviruses in wastewater and combined sewer overflows influencing a Michigan river. Applied and Environmental Microbiology, 76(3), 715-23. doi:10.1128/AEM.01316-09

Frahm, E., \& Obst, U. (2003). Application of the fluorogenic probe technique (TaqMan PCR) to the detection of Enterococcus spp. and Escherichia coli in water samples. Journal of Microbiological Methods, 52(1), 123-31. doi:10.1016/s0167-7012(02)00150-1

Genz, A., Bretz, F., Miwa, T., Mi, X., Leisch, F., Scheipl, F., \& Hothorn, T. (2021). mvtnorm: Multivariate Normal and t Distributions. Retrieved from http://CRAN.Rproject.org/package=mvtnorm.

Guix, S., Caballero, S., Villena, C., Bartolome, R., Latorre, C., Rabella, N., Simó, M., Bosch, A., \& Pinto, R. M. (2002, January). Molecular epidemiology of astrovirus infection in Barcelona, Spain. Journal of Clinical Microbiology, 40(1), 133-139. doi:10.1128/Jcm.40.1.133-139.2002.

Hamza, H., Rizk, N. M., Gad, M. A., \& Hamza, I. A. (2019, November). Pepper mild mottle virus in wastewater in Egypt: a potential indicator of wastewater pollution and the 
658

659

660

661

662

663

664

665

666

667

668

669

670

671

672

673

674

675

676

677

678

679

efficiency of the treatment process. Archives of Virology, 164(11), 2707-2713.

doi:10.1007/s00705-019-04383-x

Haramoto, E., Katayama, H., Phanuwan, C., \& Ohgaki, S. (2008, March). Quantitative detection of sapoviruses in wastewater and river water in Japan. Letters in Applied Microbiology, 46(3), 408-13. doi:10.1111/j.1472-765X.2008.02330.x

Harrell Jr., F. E. (2021). Hmisc: Harrell Miscellaneous. Retrieved from https://CRAN.Rproject.org/package $=$ Hmisc

Hood, M. A., Ness, G. E., \& Blake, N. J. (1983). Relationship among fecal coliforms, Escherichia coli, and Salmonella spp. in shellfish. Applied and environmental microbiology, 45(1), 122-126. doi:10.1128/aem.45.1.122-126.1983

Ibrahim, C., Hammami, S., Khelifi, N., Pothier, P., \& Hassen, A. (2020). The Effectiveness of Activated Sludge Procedure and UV-C 254 in Norovirus Inactivation in a Tunisian Industrial Wastewater Treatment Plant. Food and Environmental Virology, 12, 250-259. doi:10.1007/s12560-020-09434-0.

Jankowski, P., Gan, J., Le, T., McKennitt, M., Garcia, A., Yanaç, K., Yuan, Q., \& UyaguariDiaz, M. (2022, January). Metagenomic community composition and resistome analysis in a full-scale cold climate wastewater treatment plant. Environmental Microbiome, 17(1), 3. doi:10.1186/s40793-022-00398-1.

Jikumaru, A., Ishii, S., Fukudome, T., Kawahara, Y., Iguchi, A., Masago, Y., . . Suzuki, Y. (2020, July). Fast, sensitive, and reliable detection of waterborne pathogens by digital PCR after coagulation and foam concentration. Journal of Bioscience and Bioengineering, 130(1), 76-81. doi:10.1016/j.jbiosc.2020.02.004 
680 Jumat, M. R., Hasan, N. A., Subramanian, P., Heberling, C., Colwell, R. R., \& Hong, P.-Y.

681 (2017). Membrane Bioreactor-Based Wastewater Treatment Plant in Saudi Arabia:

682

683 Reduction of Viral Diversity, Load, and Infectious Capacity. Water, 9(7).

684

685

686

687

688 doi:10.3390/w9070534

Kageyama, T., Kojima, S., Shinohara, M., Uchida, K., Fukushi, S., Hoshino, F. B., Takeda, N., \& Katayama, K. (2003, April). Broadly Reactive and Highly Sensitive Assay for Norwalk-Like Viruses Based on Real-Time Quantitative Reverse Transcription-PCR.

689

Karim, M. R., Rhodes, E. R., Brinkman, N., Wymer, L., \& Fout, G. S. (2009, April). New Electropositive Filter for Concentrating Enteroviruses and Noroviruses from Large

691

692 Journal of Clinical Microbiology, 41(4), 1548-1557. doi:10.1128/JCM.41.4.15481557.2003

693

Kitajima, M., Iker, B. C., Pepper, I. L., \& Gerba, C. P. (2014, August 1). Relative abundance and 694

695

696 Volumes of Water. Applied and Environmental Microbiology, 75(8), 2393-2399.

La Rosa, G., Bonadonna, L., Lucentini, L., Kenmoe, S., \& Suffredini, E. (2020, July 15).

698 Coronavirus in water environments: Occurrence, persistence and concentration methods -

699 A scoping review. Water Research, 179. doi:10.1016/j.watres.2020.115899

700

Li, D., Gu, A. Z., Zeng, S.-Y., Yang, W., He, M., \& Shi, H.-C. (2011, May). Monitoring and 701 evaluation of infectious rotaviruses in various wastewater effluents and receiving waters 
702

703

704

705

706

707

708

709

710

711

712

713

714

715

716

717

718

719

720

721

722

723

revealed correlation and seasonal pattern of occurrences. Journal of Applied Microbiology, 110(5), 1129-37. doi:10.1111/j.1365-2672.2011.04954.x

Li, X., Cheng, Z., Dang, C., Zhang, M., Zheng, Y., \& Xia, Y. (2021, July). Metagenomic and viromic data mining reveals viral threats in biologically treated domestic wastewater. Environmental Science and Ecotechnology, 7. doi:10.1016/j.ese.2021.100105

Lizasoain, A., Tort, L., García, M., Gillman, L., Alberti, A., Leite, J., . . Colina, R. (2017). Human enteric viruses in a wastewater treatment plant: evaluation of activated sludge combined with UV disinfection process reveals different removal performances for viruses with different features. Letters in Applied Microbiology, 66(3), 215-221. https://doi.org/10.1111/lam.12839

Makowski, D., Ben-Shachar, M., Patil, I., \& Lüdecke, D. (2020). Automated Results Reporting as a Practical Tool to Improve Reproducibility and Methodological Best Practices Adoption. Retrieved from https://github.com/easystats/report.

Mbanga, J., Abia, A. L., Amoako, D. G., \& Essack, S. Y. (2020). Quantitative microbial risk assessment for waterborne pathogens in a wastewater treatment plant and its receiving surface water body. BMC Microbiology. doi:10.1186/s12866-020-02036-7

Mezzanotte, V., Antonelli, M., Citterio, S., \& Nurizzo, C. (2007). Wastewater disinfection alternatives: chlorine, ozone, peracetic acid, and UV light. Water Environment Research, 79(12), 2373-2379. doi:10.2175/106143007x183763.

Miura, T., Okabe, S., Nakahara, Y., \& Sano, D. (2015, May 15). Removal properties of human enteric viruses in a pilot-scale membrane bioreactor (MBR) process. Water Research, 75, 282-291. doi:10.1016/j.watres.2015.02.046 
724 Molecular Microbiology \& Genomics Team, British Columbia Centre for Disease Control.

725 (2017). Detecting Norovirus by Fast Real-Time RT-PCR. British Columbia, Canada.

726 Molecular Microbiology \& Genomics Team, British Columbia Centre for Disease Control.

727 (2017). Performing the GI Virus Panel by Real-Time PCR Procedure. British Columbia,

728 Canada.

729 Murphy, H. (2017). Persistence of Pathogens in Sewage and Other Water Types. In J. Rose, \& B.

730 Jiménez-Cisneros (Eds.), Global Water Pathogen Project (Vol. 4). E. Lansing, MI, $731 \quad$ UNESCO. doi:10.14321/waterpathogens.51

732 Nguyen, S. T., Roddick, F. A., \& Harris, J. L. (2010). Membrane foulants and fouling

733 mechanisms in microfiltration and ultrafiltration of an activated sludge effluent. Water

$734 \quad$ Science and Technology, 62(9), 1975-1983. https://doi.org/10.2166/wst.2010.505

735 Nour, I., Hanif, A., Zakri, A. M., Al-Ashkar, I., Alhetheel, A., \& Eifan, S. (2021, April 29).

736

737

738

739

740

Oka, T., Katayama, K., Hansman, G. S., Kageyama, T., Ogawa, S., Wu, F.-T., . . Takeda, N. (2006). Detection of human sapovirus by real-time reverse transcription-polymerase

742 Pérez, M. V., Guerrero, L. D., Orellana, E., Figuerola, E. L., \& Erijman, L. (2019, July 2). Time Series Genome-Centric Analysis Unveils Bacterial Response to Operational Disturbance in Activated Sludge. mSystems, 4(4). doi:10.1128/mSystems.00169-19

745 Prevost, B., Lucas, F. S., Ambert-Balay, K., Pothier, P., Moulin, L., \& Wurtzer, S. (2015, 746 October). Deciphering the Diversities of Astroviruses and Noroviruses in Wastewater 
747

748

749

750

751

752

753

754

755

756

757

758

759

760

761

762

763

764

765

766

767

768

Treatment Plant Effluents by a High-Throughput Sequencing Method. Applied and Environmental Microbiology, 81(20), 7215-7222. doi:10.1128/AEM.02076-15.

R Core Team. (2021). R: A language and environment for statistical computing. R Foundation for Statistical Computing, Vienna, Austria. Retrieved from https://www.R-project.org/

Racz, L., T. Datta, \& R. Goel. 2010. Effect of organic carbon on ammonia oxidizing bacteria in a mixed culture. Bioresource Technology, 101 (16), 6454-60.

Raeiszadeh, M., \& Adeli, B. (2020, October 14). A Critical Review on Ultraviolet Disinfection Systems against COVID-19 Outbreak: Applicability, Validation, and Safety Considerations. ACS Photonics. doi:10.1021/acsphotonics.0c01245

Ritalahti, K. M., Amos, B. K., Sung, Y., Wu, Q., Koenigsberg, S. S., \& Löffler, F. E. (2006). Quantitative PCR targeting 16S rRNA and reductive dehalogenase genes simultaneously monitors multiple Dehalococcoides strains. Applied and Environmental Microbiology, 72(4), 2765-74. doi:10.1128/AEM.72.4.2765-2774.2006

Rosario, K., Symonds, E. M., Sinigalliano, C., Stewart, J., \& Breitbart, M. (2009). Pepper Mild Mottle Virus as an Indicator of Fecal Pollution. Applied and Environmental Microbiology, 75(22), 7261-7267. doi:10.1128/AEM.00410-09

Rosman, N. H., Anuar, A. N., Chelliapan, S., Din, M. F., \& Ujang, Z. (2014, June). Characteristics and performance of aerobic granular sludge treating rubber wastewater at different hydraulic retention time. Bioresource Technology, 161, 155-61. doi:10.1016/j.biortech.2014.03.047

RStudio Team. (2021). RStudio: Integrated Development Environment for R. Boston, MA: RStudio, PBC. Retrieved from http://www.rstudio.com/ 
769 Ruggeri, F. M., Bonomo, P., Ianiro, G., Battistone, A., Delogu, R., Germinario, C., Chironna,

770

771

772

773

774

775

776

777

778

779

780

781

782

783

784

785

786

787

788

789

790

791

M., Triassi, M., Campagnuolo, R., Cicala, A., Giammanco, G. M., Castiglia, P., Serra, C., Gaggioli, A., \& Fiore, L. (2015, January). Rotavirus Genotypes in Sewage Treatment Plants and in Children Hospitalized with Acute Diarrhea in Italy in 2010 and 2011. Applied and Environmental Microbiology, 81(1), 241-249. doi:10.1128/AEM.02695-14.

Sánchez, G. \& A. Bosch. (August 26, 2016). Survival of Enteric Viruses in the Environment and Food. Viruses in Food, Food Microbiology and Food Safety. Chapter 13: 367-392. doi: 10.1007/978-3-319-30723-7_13

Sarkar, D. (2008). Lattice: Multivariate Data Visualization with R. New York: Springer.

Scholz, M. Chapter 15-Activated Sludge Processes, Editor(s): Miklas Scholz, Wetlands for Water Pollution Control (Second Edition), Elsevier, Pages 91-105.

Schmitz, B. W., Kitajima, M., Campillo, M. E., Gerba, C. P., \& Pepper, I. L. (2016). Virus Reduction during Advanced Bardenpho and Conventional Wastewater Treatment Processes. Environmental Science \& Technology, 50(17), 9524-9532. doi:10.1021/acs.est.6b01384.

Shelford, E. J., \& Suttle, C. A. (2018). Virus-mediated transfer of nitrogen from heterotrophic bacteria to phytoplankton. Biogeosciences, 15(3), 809-819. doi:10.5194/bg-15-809-2018

Sima, L. C., Schaeffer, J., Saux, J.-C. L., Parnaudeau, S., Elimelech, M., \& Guyader, F. S. (2011, August). Calicivirus Removal in a Membrane Bioreactor Wastewater Treatment Plant. Applied and Environmental Microbiology, 77(15), 5170-5177. doi:10.1128/AEM.0058311.

Sizirici, B., \& Yildiz, I. (2020). Organic matter removal via activated sludge immobilized gravel in fixed bed reactor. E3S Web of Conferences, 191, 03006, 1-5. 
792 Song, K., Lin, X., Liu, Y., Ji, F., Zhang, L., Chen, P., . . Xu, A. (2021). Detection of Human

793 Sapoviruses in Sewage in China by Next Generation Sequencing. Food and

794 Environmental Virology, 13, 270-280. doi:10.1007/s12560-021-09469-х

795 Stachler, E., Akyon, B., Carvalho, N. A., Ference, C., \& Bibby, K. (2018). Correlation of 796 crAssphage qPCR Markers with Culturable and Molecular Indicators of Human Fecal

797

798 Pollution in an Impacted Urban Watershed. Environmental Science \& Technology, 52(13), 7505-7512. doi:10.1021/acs.est.8b00638

Stachler, E., Kelty, C., Sivaganesan, M., Li, X., Bibby, K., \& Shanks, O. C. (2017). Quantitative 800

801 CrAssphage PCR Assays for Human Fecal Pollution Measurement. Environmental Science \& Technology, 51(16), 9146-9154. doi:10.1021/acs.est.7b02703

Symonds, E. M., Nguyen, K. H., \& Breitbart, M. (2018). Pepper mild mottle virus: A plant 803 pathogen with a greater purpose in (waste)water treatment development and public health 804 management. Water Research, Nov 1; 144: 1-12. doi:10.1016/j.watres.2018.06.066 805 806

Tandukar, S., Sherchan, S. P., \& Haramoto, E. (2020). Applicability of crAssphage, pepper mild mottle virus, and tobacco mosaic virus as indicators of reduction of enteric viruses during 807 wastewater treatment. Scientific Reports, 10(3616). doi:10.1038/s41598-020-60547-9

Templeton M.R. Butler D. (2011). Introduction to wastewater treatment. Bookboon London, UK. 809 810 Therneau, T. (2021). A Package for Survival Analysis in R. Retrieved from https://CRAN.Rproject.org/package $=$ survival

811 Ushey, K., Allaire, J., Wickham, H., \& Ritchie, G. (2020). rstudioapi: Safely Access the RStudio 812 API. Retrieved from https://CRAN.R-project.org/package=rstudioapi

813 Uyaguari-Diaz, M. I., Chan, M., Chaban, B. L., Croxen, M. A., Finke, J. F., Hill, J. E., ... Tang, 814 P. (2016). A comprehensive method for amplicon-based and metagenomic 
characterization of viruses, bacteria, and eukaryotes in freshwater samples. Microbiome,

816 4(20). doi:10.1186/s40168-016-0166-1

817 Varela, M. F., Ouardani, I., Kato, T., Kadoya, S., Aouni, M., Sano, D., \& Romalde, J. L. (2018,

818 March 1). Sapovirus in Wastewater Treatment Plants in Tunisia: Prevalence, Removal, and Genetic Characterization. Applied and Environmental Microbiology, 84(6).

820 doi:10.1128/AEM.02093-17

821 Vu, V. Q. (2011). ggbiplot: A ggplot2 based biplot. Retrieved from

822 http://github.com/vqv/ggbiplot

823 Wang, X. M., Wei, Z. M., Guo, J. M., Cai, J. M., Chang, H. M., Ge, Y. M., \& Zeng, M. M.

824

825

826 (2019, November). Norovirus Activity and Genotypes in Sporadic Acute Diarrhea in Children in Shanghai During 2014-2018. The Pediatric Infectious Disease Journal, 38(11), 1085-1089. doi:10.1097/INF.0000000000002456

Weather Spark. (2022, January 16). Available from:

\section{0}

831

832 833

834

835

836 https://weatherspark.com/h/m/96939/1998/11/Historical-Weather-in-November-1998-inCairo-Egypt\#Figures-Temperature

Wickham, H. (2011). The Split-Apply-Combine Strategy for Data Analysis. Journal of Statistical Software, 40(1), 1-29. doi:10.18637/jss.v040.i01

Wickham, H. (2016). ggplot2: Elegant Graphics for Data Analysis. New York: Springer-Verlag.

Wickham, H. (2020, April 9). reshape2: Flexibly Reshape Data: A Reboot of the Reshape Package. Retrieved from https://cran.r-project.org/package=reshape2

Wickham, H., \& Bryan, J. (2019). readxl: Read Excel Files. Retrieved from https://CRAN.Rproject.org/package $=$ readxl 
837 Wickham, H., \& Bryan, J. (2021). usethis: Automate Package and Project Setup. Retrieved from 838 https://CRAN.R-project.org/package=usethis

839 Wickham, H., \& Seidel, D. (2020). scales: Scale Functions for Visualization. Retrieved from 840 https://CRAN.R-project.org/package=scales

841 Wickham, H., François, R., Henry, L., \& Müller, K. (2021). dplyr: A Grammar of Data

842 Manipulation. Retrieved from https://CRAN.R-project.org/package=dplyr

843 Wickham, H., Hester, J., \& Chang, W. (2021). devtools: Tools to Make Developing R Packages 844 Easier. Retrieved from https://CRAN.R-project.org/package=devtools

845 Worley-Morse, T., Mann, M., Khunjar, W., Olabode, L., \& Gonzalez, R. (2019, September).

846

847 Evaluating the fate of bacterial indicators, viral indicators, and viruses in water resource recovery facilities. Water Environment Research, 91(9), 830-842. doi:10.1002/wer.1096.

848 Wu, Z., Greaves, J., Arp, L., Stone, D., \& Bibby, K. (2020, March). Comparative fate of CrAssphage with culturable and molecular fecal pollution indicators during activated 850 sludge wastewater treatment. Environment International, 136: 105452.

851 https://doi.org/10.1016/j.envint.2019.105452.

852 Yanaç, K., Adegoke, A., Wang, L., Yuan, Q., \& Uyaguari, M. (2021, October). Detection of SARS-CoV-2 RNA Throughout Wastewater Treatment Plants and A Modeling Approach to Understand COVID-19 Infection Dynamics in Winnipeg, Canada. Available from medRxiv: $\underline{\text { https://doi.org/10.1101/2021.10.26.21265146 }}$

Ye, J., Coulouris, G., Zaretskaya, I., Cutcutache, I., Rozen, S., \& Madden, T. L. (2012, June 18). 857 Primer-BLAST: a tool to design target-specific primers for polymerase chain reaction. BMC Bioinformatics, 13(134). doi:10.1186/1471-2105-13-134 
859 Zeileis, A., \& Croissant, Y. (2010). Extended Model Formulas in R: Multiple Parts and Multiple 860 Responses. Journal of Statistical Software, 34(1), 1-13. doi:10.18637/jss.v034.i01

861 Zeng, S. Q., Halkosalo, A., Salminen, M., Szakal, E. D., Puustinen, L., \& Vesikari, T. (2008).

862 One-step quantitative RT-PCR for the detection of rotavirus in acute gastroenteritis.

863 Journal of Virological Methods, 153(2), 238-40. doi:10.1016/j.jviromet.2008.08.004

864 Zhang, T., Breitbart, M., Lee, W. H., Run, J.-Q., Wei, C. L., Soh, S. W., Hibberd, M. L., Liu, E.

865 T., Rohwer, F., \& Ruan, Y. (2006, January). RNA Viral Community in Human Feces:

866 Prevalence of Plant Pathogenic Viruses. PLOS Biology, 4(1).

867 doi:10.1371/journal.pbio.0040003

868 Zhao, Y., Liu, D., Huang, W., Yang, Y., Ji, M., Nghiem, L. D., Trinh, Q. T., Tran, N. H. (2018).

869 Insights into biofilm carriers for biological wastewater treatment processes: Current state-

870 of-the-art, challenges, and opportunities. Bioresource Technology, 288, 121619.

$871 \quad$ doi.org/10.1016/j.biortech.2019.121619. 


\section{Table $\mathbf{1}$ (on next page)}

Table 1. Primers and probes used in the present study. 


\begin{tabular}{|c|c|c|c|c|c|}
\hline Target & $\begin{array}{c}\text { DNA } \\
\text { or } \\
\text { RNA }\end{array}$ & $\begin{array}{l}\text { Primer/ } \\
\text { Probe }\end{array}$ & Sequence (5'-3') & $\begin{array}{l}\text { Genomic } \\
\text { Target }\end{array}$ & References \\
\hline \multirow{3}{*}{$\begin{array}{l}\text { Adenovirus } \\
\quad 40 / 41\end{array}$} & \multirow{3}{*}{ DNA } & AdV-F & GCC TGG GGA ACA AGT TCA G & \multirow{3}{*}{ Hexon } & \multirow{3}{*}{$\begin{array}{c}\text { Molecular Microbiology \& Genomics } \\
\text { Team, } \\
\text { British Columbia Centre for Disease } \\
\text { Control, 2017a }\end{array}$} \\
\hline & & AdV-R & ACG GCC AGC GTA AAG CG & & \\
\hline & & $\begin{array}{l}\text { AdV-P } \\
\text { (Probe) }\end{array}$ & $\begin{array}{l}\text { NED-ACC CAC GAT GTA ACC AC- } \\
\text { MGB-NFQ }\end{array}$ & & \\
\hline \multirow{3}{*}{ Astrovirus } & \multirow{3}{*}{ RNA } & Ast-F & AAG CAG CTT CGT GAR TCT GG & \multirow{3}{*}{$\begin{array}{l}\text { Junction of } \\
\text { polymerase } \\
\text { and capsid }\end{array}$} & \multirow{3}{*}{$\begin{array}{c}\text { Molecular Microbiology \& Genomics } \\
\text { Team, } \\
\text { British Columbia Centre for Disease } \\
\text { Control, 2017a }\end{array}$} \\
\hline & & Ast-R & GCC ATC RCA CTT CTT TGG TCC & & \\
\hline & & $\begin{array}{l}\text { Ast-P } \\
\text { (Probe) }\end{array}$ & $\begin{array}{l}\text { Cy5-CAC AGA AGA GCA ACT CCA TCG } \\
\text { CAT TTG-Tao-IBDRQ }\end{array}$ & & \\
\hline \multirow{3}{*}{ crAssphage } & \multirow{3}{*}{ DNA } & $056 \mathrm{~F} 1$ & $\begin{array}{l}\text { CAG AAG TAC AAA CTC CTA AAA } \\
\text { AAC GTA GAG }\end{array}$ & \multirow{3}{*}{$\begin{array}{l}\text { Genomic } \\
\text { base pair } \\
\text { region: } \\
14731 \mathrm{bp}- \\
14856 \mathrm{bp}\end{array}$} & \multirow{3}{*}{$\begin{array}{l}\text { Stachler, Akyon, Carvalho, Ference, } \\
\text { \& Bibby, } 2018\end{array}$} \\
\hline & & 056R1 & $\begin{array}{l}\text { GAT GAC CAA TAA ACA AGC CAT } \\
\text { TAG C }\end{array}$ & & \\
\hline & & 056P1 & $\begin{array}{l}\text { FAM-AAT AAC GAT TTA CGT GAT } \\
\text { GTA AC }\end{array}$ & & \\
\hline \multirow{3}{*}{$\begin{array}{l}\text { Escherichia } \\
\text { coli }\end{array}$} & \multirow{3}{*}{ DNA } & $784 \mathrm{~F}$ & GTG TGA TAT CTA CCC GCT TCG C & \multirow{3}{*}{ uidA } & \multirow{3}{*}{ Frahm and Obst, 2003} \\
\hline & & $866 \mathrm{R}$ & $\begin{array}{l}\text { AGA ACG GTT TGT GGT TAA TCA } \\
\text { GGA }\end{array}$ & & \\
\hline & & $\begin{array}{l}\mathrm{EC} 807 \\
\text { (Probe) } \\
\end{array}$ & $\begin{array}{l}\text { FAM-TCG GCA TCC GGT CAG TGG } \\
\text { CAG T-BHQ1 }\end{array}$ & & \\
\hline \multirow{3}{*}{ GI } & \multirow{3}{*}{ RNA } & $\begin{array}{l}\text { COG1F- } \\
\text { flap }\end{array}$ & $\begin{array}{l}\text { AATAAATCATAACGYTGGATGCGNTT } \\
\text { YCATGA }\end{array}$ & \multirow{3}{*}{$\begin{array}{l}\text { Norovirus } \\
\quad \text { GI }\end{array}$} & \multirow{2}{*}{$\begin{array}{l}\text { Kageyama, et al., 2003; Wang, et al., } \\
2019\end{array}$} \\
\hline & & $\begin{array}{l}\text { COG1R- } \\
\text { flap }\end{array}$ & $\begin{array}{l}\text { AATAAATCATAACTTAGACGCCATCA } \\
\text { TCATTYAC }\end{array}$ & & \\
\hline & & $\begin{array}{c}\text { Ring1a.2 } \\
\text { (Probe) }\end{array}$ & $\begin{array}{l}\text { 6-FAM- AGATYGCGR/ZEN/ } \\
\text { TCYCCTGTCCA -IBFQ }\end{array}$ & & $\begin{array}{c}\text { Molecular Microbiology \& Genomics } \\
\text { Team, British Columbia Centre for } \\
\text { Disease Control, 2017b }\end{array}$ \\
\hline \multirow{3}{*}{ GII } & \multirow{3}{*}{ RNA } & $\begin{array}{l}\text { COG2F- } \\
\text { flap }\end{array}$ & $\begin{array}{l}\text { AATAAATCATAACARGARBCNATGTT } \\
\text { YAGRTGGAT GAG }\end{array}$ & \multirow{3}{*}{$\begin{array}{l}\text { Norovirus } \\
\quad \text { GII }\end{array}$} & \multirow{2}{*}{$\begin{array}{l}\text { Kageyama, et al., 2003; Wang, et al., } \\
2019\end{array}$} \\
\hline & & $\begin{array}{l}\text { COG2R- } \\
\text { flap }\end{array}$ & $\begin{array}{l}\text { AATAAATCATAATCGACGCCATCTTC } \\
\text { ATTCACA }\end{array}$ & & \\
\hline & & $\begin{array}{l}\text { Ring } 2.2 \\
\text { (Probe) }\end{array}$ & $\begin{array}{l}\text { JOE - TGGGAGGGY/ZEN/ } \\
\text { GATCGCAATCT - IBFQ }\end{array}$ & & $\begin{array}{c}\text { Molecular Microbiology \& Genomics } \\
\text { Team, British Columbia Centre for } \\
\text { Disease Control, 2017b }\end{array}$ \\
\hline \multirow[b]{3}{*}{$\begin{array}{l}\text { Pepper Mild } \\
\text { Mottle Virus }\end{array}$} & \multirow[b]{3}{*}{ RNA } & PMMV-FP & GAG TGG TTT GAC CTT AAC GTT TGA & \multirow{3}{*}{$\begin{array}{c}1878 \mathrm{bp}- \\
1901 \mathrm{bp}^{\mathrm{a}} \\
\text { and } 1945 \\
\mathrm{bp}-1926 \\
\text { bp }^{\mathrm{a}}\end{array}$} & \multirow[b]{3}{*}{$\begin{array}{l}\text { Rosario, Symonds, Sinigalliano, } \\
\text { Stewart, \& Breitbart, } 2009\end{array}$} \\
\hline & & PMMV-RP & TTG TCG GTT GCA ATG CAA GT & & \\
\hline & & $\begin{array}{l}\text { PMMV- } \\
\text { Probe }\end{array}$ & $\begin{array}{l}\text { FAM-CCT ACC GAA GCA AAT G-MGB- } \\
\text { NFQ }\end{array}$ & & \\
\hline \multirow{3}{*}{$\begin{array}{l}\text { Rotavirus } \\
\text { Type A }\end{array}$} & \multirow{3}{*}{ RNA } & $\begin{array}{l}\text { Tampere } \\
\text { NSP3-F }\end{array}$ & $\begin{array}{l}\text { ACC ATC TWC ACR TRA CCC TCT ATG } \\
\text { AG }\end{array}$ & \multirow{3}{*}{$\begin{array}{l}\text { Non- } \\
\text { structural } \\
\text { Protein } 3\end{array}$} & \\
\hline & & $\begin{array}{l}\text { Tampere } \\
\text { NSP3-R }\end{array}$ & GGT CAC ATA ACG CCC CTA TAG C & & Zeng, et al., 2008 \\
\hline & & $\begin{array}{l}\text { Tampere } \\
\text { NSP3 } \\
\text { (Probe) }\end{array}$ & $\begin{array}{l}\text { VIC-AGT TAA AAG CTA ACA CTG TCA } \\
\text { AA-MGB-NFQ }\end{array}$ & & \\
\hline & & SaV1F & TTG GCC CTC GCC ACC TAC & & \\
\hline & & SaV5F & TTT GAA CAA GCT GTG GCA TGC TAC & & \\
\hline & & $\mathrm{SaV124F}$ & GAY CAS GCT CTC GCY ACC TAC & & \\
\hline Sapovirus & RNA & $\mathrm{SaV} 1245 \mathrm{R}$ & CCC TCC ATY TCA AAC ACT A & $\begin{array}{l}\text { Junction of } \\
\text { polymerase }\end{array}$ & Oka, et al., 2006 \\
\hline & & $\begin{array}{l}\text { SaV124TP } \\
\text { (Probe) }\end{array}$ & FAM-CCR CCT ATR AAC CA-MGB-NFQ & and capsid & \\
\hline & & $\begin{array}{l}\text { SaV5TP } \\
\text { (Probe) }\end{array}$ & $\begin{array}{l}\text { FAM-TGC CAC CAA TGT ACC A-MGB- } \\
\text { NFQ }\end{array}$ & & \\
\hline
\end{tabular}




\section{Table 2 (on next page)}

Table 2. UV-treated final effluent water quality parameters measured in the North End Sewage Treatment Plant.^ 


\begin{tabular}{|c|c|c|c|c|c|c|}
\hline \multirow[b]{2}{*}{ Parameters } & \multicolumn{4}{|c|}{ Sampling Events } & \multirow[b]{2}{*}{ Mean } & \multirow[b]{2}{*}{ SD } \\
\hline & $\begin{array}{l}\text { Oct-22- } \\
2019 \\
(\# \mathbf{1})\end{array}$ & $\begin{array}{l}\text { Nov-28- } \\
2019 \\
(\# \mathbf{2}) \\
\end{array}$ & $\begin{array}{l}\text { Dec-18- } \\
2019 \\
(\# \mathbf{3}) \\
\end{array}$ & $\begin{array}{l}\text { Feb-6- } \\
2020 \\
(\# 4)\end{array}$ & & \\
\hline $\mathrm{BOD}(\mathrm{mg} / \mathrm{L})$ & $19.5^{\dagger}$ & 13 & 18 & 26 & 19.13 & 4.64 \\
\hline $\mathrm{cBOD}(\mathrm{mg} / \mathrm{L})$ & 4 & 5 & 7 & 7 & 5.8 & 1.5 \\
\hline $\mathrm{COD}(\mathrm{mg} / \mathrm{L})$ & $51.5^{\dagger}$ & 66 & 94 & 89 & 75.13 & 17.25 \\
\hline $\begin{array}{l}\mathrm{sCOD}(\mathrm{mg} / \mathrm{L}) \\
\text { E. coli }(\text { counts } / 100\end{array}$ & 25 & 51 & 68 & 63 & 51.8 & 19.2 \\
\hline $\mathrm{ml})$ & 60 & 60 & 90 & 1080 & 322.5 & 437.5 \\
\hline $\begin{array}{l}\text { Fecal coliforms } \\
\text { (counts } / 100 \mathrm{ml} \text { ) }\end{array}$ & 100 & 20 & 40 & 640 & 200 & 295.3 \\
\hline $\begin{array}{l}\text { Grab Temperature } \\
\left({ }^{\circ} \mathrm{C}\right) \\
\text { Mean (Ambient) }\end{array}$ & 13.4 & 14.1 & 14.1 & 12.7 & 13.6 & 0.7 \\
\hline Temperature $\left({ }^{\circ} \mathrm{C}\right)$ & 2.7 & -6.6 & -17.0 & -17.1 & -9.5 & 9.5 \\
\hline $\mathrm{NH}_{4}-\mathrm{N}(\mathrm{mg} / \mathrm{L})$ & 5.9 & 26.3 & 34.3 & 34.9 & 25.4 & 13.5 \\
\hline $\mathrm{NO}_{\mathrm{x}}-\mathrm{N}(\mathrm{mg} / \mathrm{L})$ & 7.5 & 5.3 & 3.3 & 2.1 & 4.5 & 2.4 \\
\hline $\mathrm{pH}$ & 7.12 & 6.81 & 6.79 & 6.99 & 6.93 & 0.14 \\
\hline PO4-P (mg/L) & 1.3 & 2.6 & 1.2 & 1.0 & 1.5 & 0.7 \\
\hline Precipitation $(\mathrm{mm})^{*}$ & 4.8 & 0 & 1 & 1.6 & 1.85 & 1.8 \\
\hline $\mathrm{TN}(\mathrm{mg} / \mathrm{L})$ & $15.4^{\dagger}$ & 40.7 & 49.8 & 50.5 & 39.1 & 14.22 \\
\hline TOC (mg/L) & $19.8^{\dagger}$ & 21.2 & 29.6 & 34.4 & 26.25 & 6.02 \\
\hline $\mathrm{TP}(\mathrm{mg} / \mathrm{L})$ & $1.67^{\dagger}$ & 3.43 & 1.69 & 1.69 & 2.12 & 0.76 \\
\hline $\mathrm{TS}(\mathrm{mg} / \mathrm{L})$ & 1,065 & 886 & 818 & 598 & 841.8 & 193 \\
\hline $\mathrm{TSS}(\mathrm{mg} / \mathrm{L})$ & $19.5^{\dagger}$ & 6 & 10 & 18 & 13.38 & 5.58 \\
\hline Turbidity (NTU) & $12.25^{\dagger}$ & 4.2 & 6.3 & 9.2 & 7.99 & 3.03 \\
\hline grab filtered UVT $(\%)$ & 56.7 & 52.1 & 45.8 & 46.9 & 50.4 & 4.4 \\
\hline
\end{tabular}

1 BOD, biochemical oxygen demand; cBOD, Carbonaceous Biochemical Oxygen Demand; COD,

2 chemical oxygen demand; sCOD, soluble chemical oxygen demand; $\mathrm{NH}_{4}-\mathrm{N}$, ammonium-nitrogen;

$3 \mathrm{NO}_{\mathrm{x}} \mathrm{-N}$, nitrogen oxides - nitrogen; $\mathrm{PO}_{4}-\mathrm{P}$, orthophosphate; $\mathrm{TN}$, total nitrogen; $\mathrm{TP}$, total phosphorus;

4 TOC, total organic carbon; TS, total solids; TSS, total suspended solids; UVT, Ultraviolet

5 transmittance.

$6 *$ Cumulative amount of rainfall over three days.

7 Parameters measured the day before and the day after were averaged and used to estimate

8 parameters of sample date.

$9 \wedge$ modified from Jankowski et al., 2022. 
Figure 1

Figure 1. Graphical abstract of workflow.

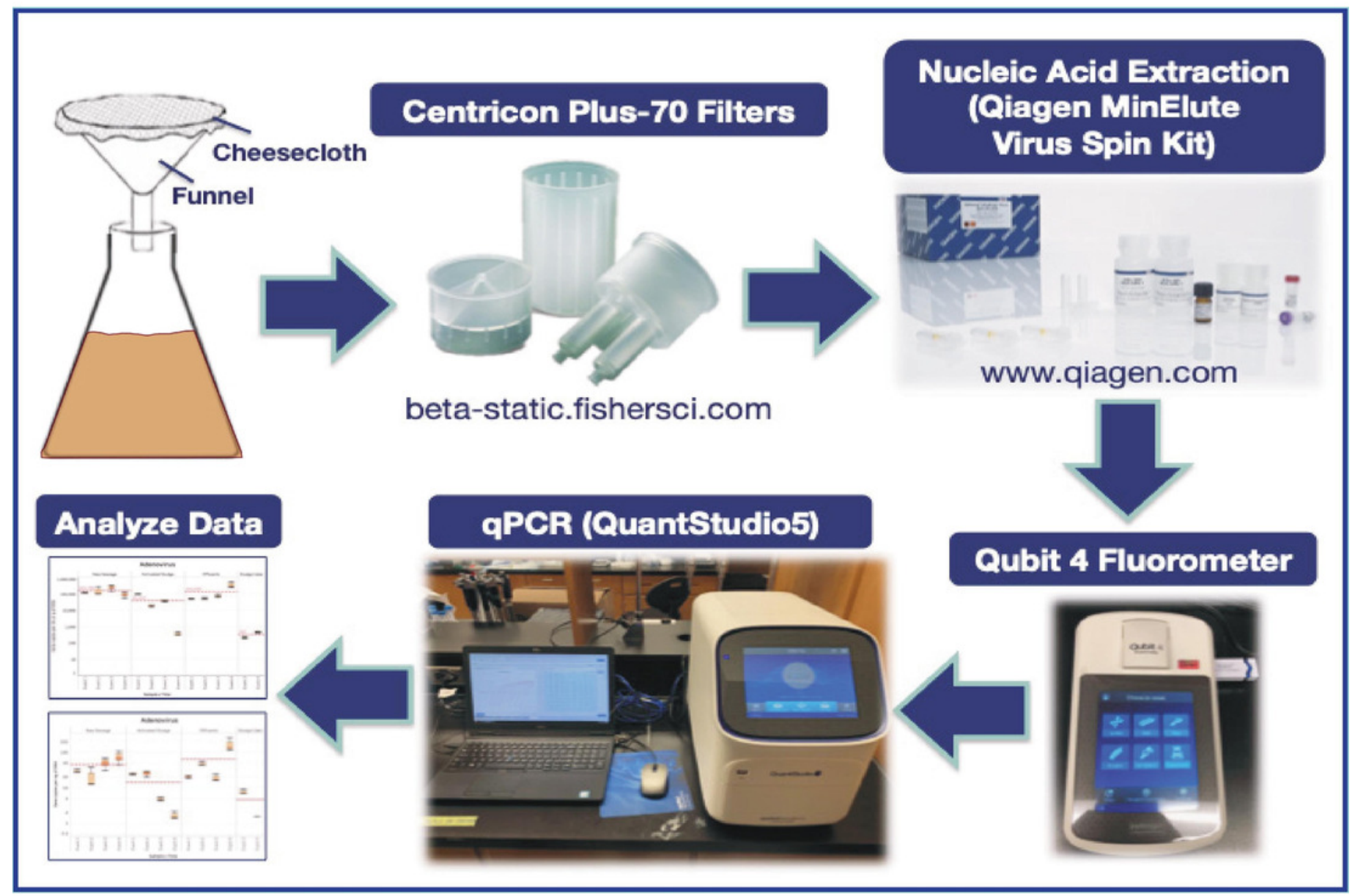




\section{Figure 2}

Figure 2. Box plots of the number of gene copies of DNA enteric viruses across each wastewater stage throughout Events 1-4.

Figures $2 \mathrm{~A}$ and $2 \mathrm{C}$ visualize the number of gene copies per $\mathrm{mL}$ or $\mathrm{g}$ of sample, while Fig. $2 B$ and Fig. 2D visualize the number of gene copies per ng of DNA. In Fig. 2A, Fig. 2C, and Fig. $2 D$ these quantities were $\log _{10}$-transformed for aesthetic purposes. The unit for the SC in Fig. $2 A$ and Fig. $2 C$ is gene copies per $g$ of sample. Means with different letters indicate significant differences at the 0.05 level across treatments.
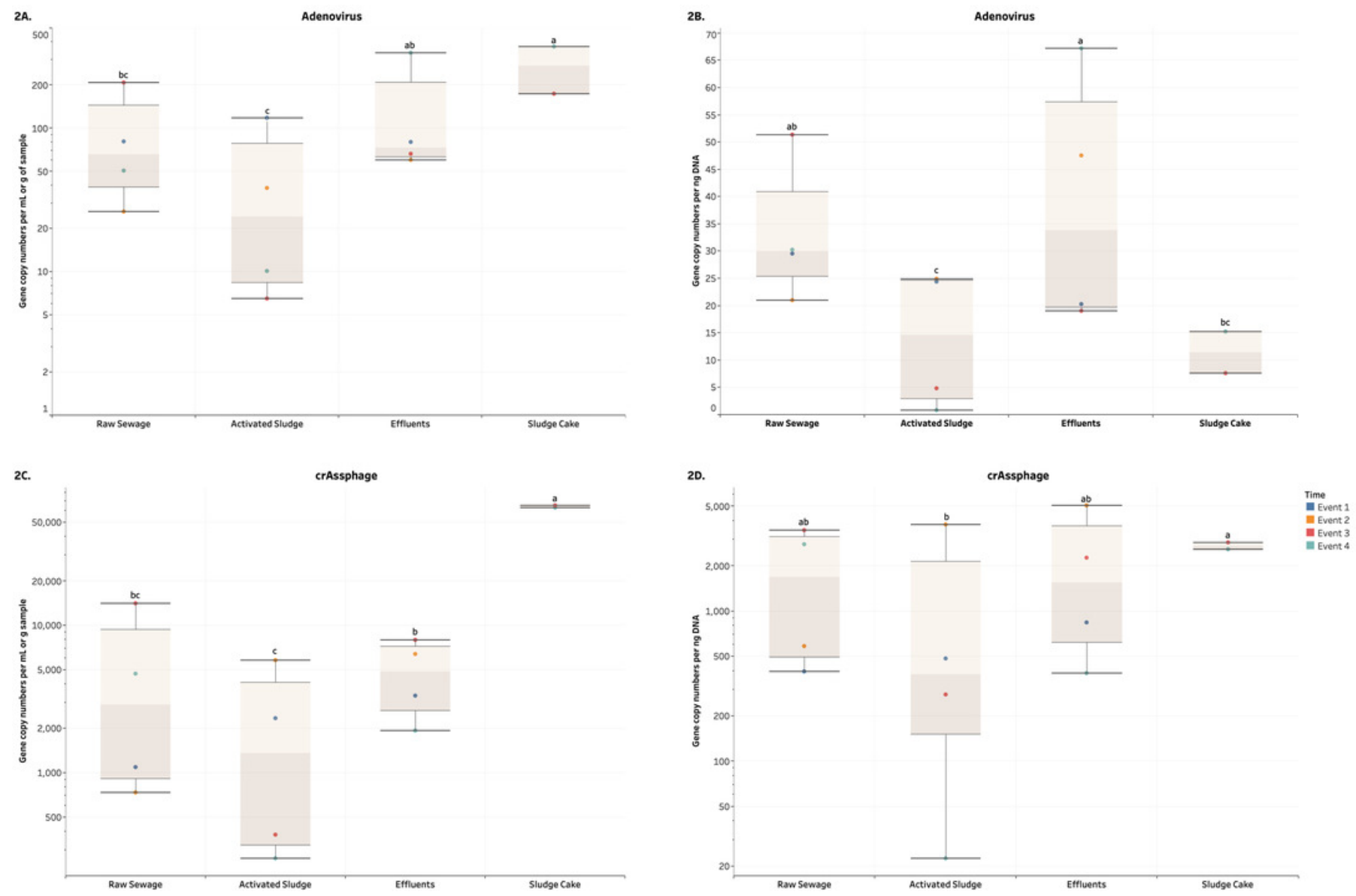


\section{Figure 3}

Figure 3. Box plots of the number of genes copies of PMMV across each wastewater stage throughout Events 1-4.

Figure $3 A$ visualizes the number of gene copies per $\mathrm{mL}$ or $\mathrm{g}$ of sample, while Fig. $3 B$ visualizes the number of gene copies per ng of DNA. Both quantities were $\log _{10}$-transformed for aesthetic purposes. The unit for the SC in Fig. $3 A$ is gene copies per $g$ of sample. Means with different letters indicate significant differences at the 0.05 level across treatments.
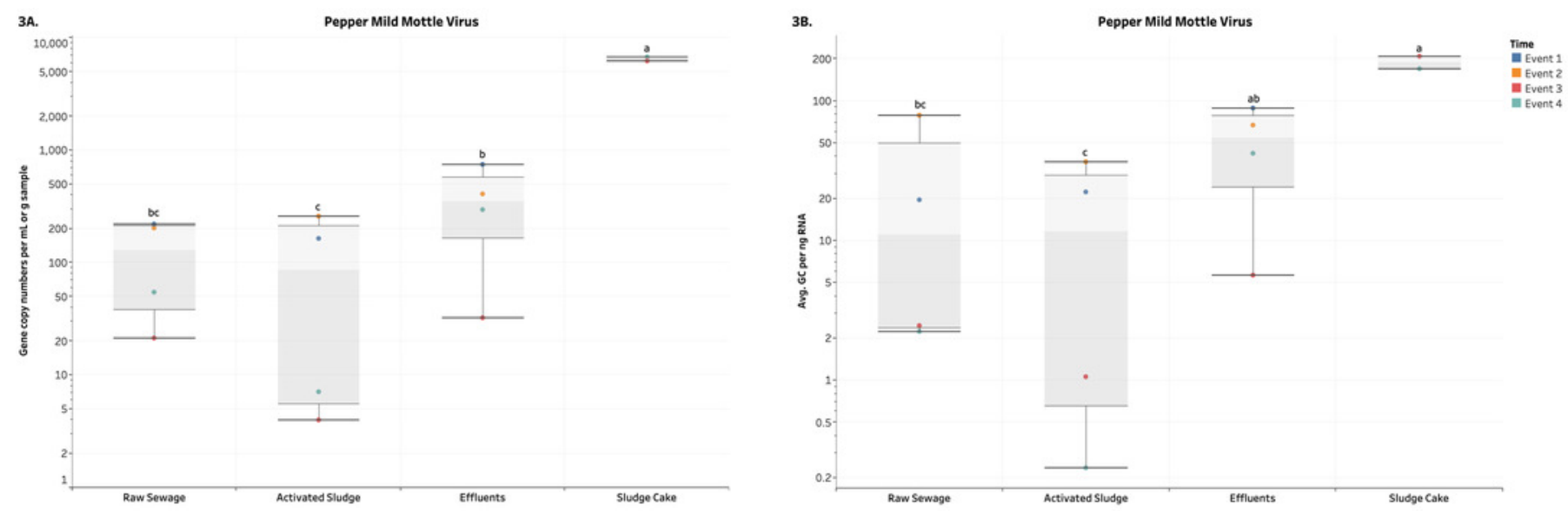


\section{Figure 4}

Figure 4. Box plots of the number of gene copies of uidA across each wastewater stage throughout Events 1-4.

Figure $4 \mathrm{~A}$ visualizes the number of gene copies per $\mathrm{mL}$ or $\mathrm{g}$ of sample, while Fig. $4 B$ visualizes the number of gene copies per ng of DNA. Both quantities were $\log _{10}$-transformed for aesthetic purposes. The unit for the SC in Fig. $4 A$ is gene copies per $\mathrm{g}$ of sample. Means with different letters indicate significant differences at the 0.05 level across treatments.

Figure 5

Figure 5. Principal Component Analysis of $\log _{10}$-transformed EF parameters, $\mathrm{PC} 1$ versus PC2.

The only variable not $\log _{10}$-transformed was precipitation due to presence of zero values.

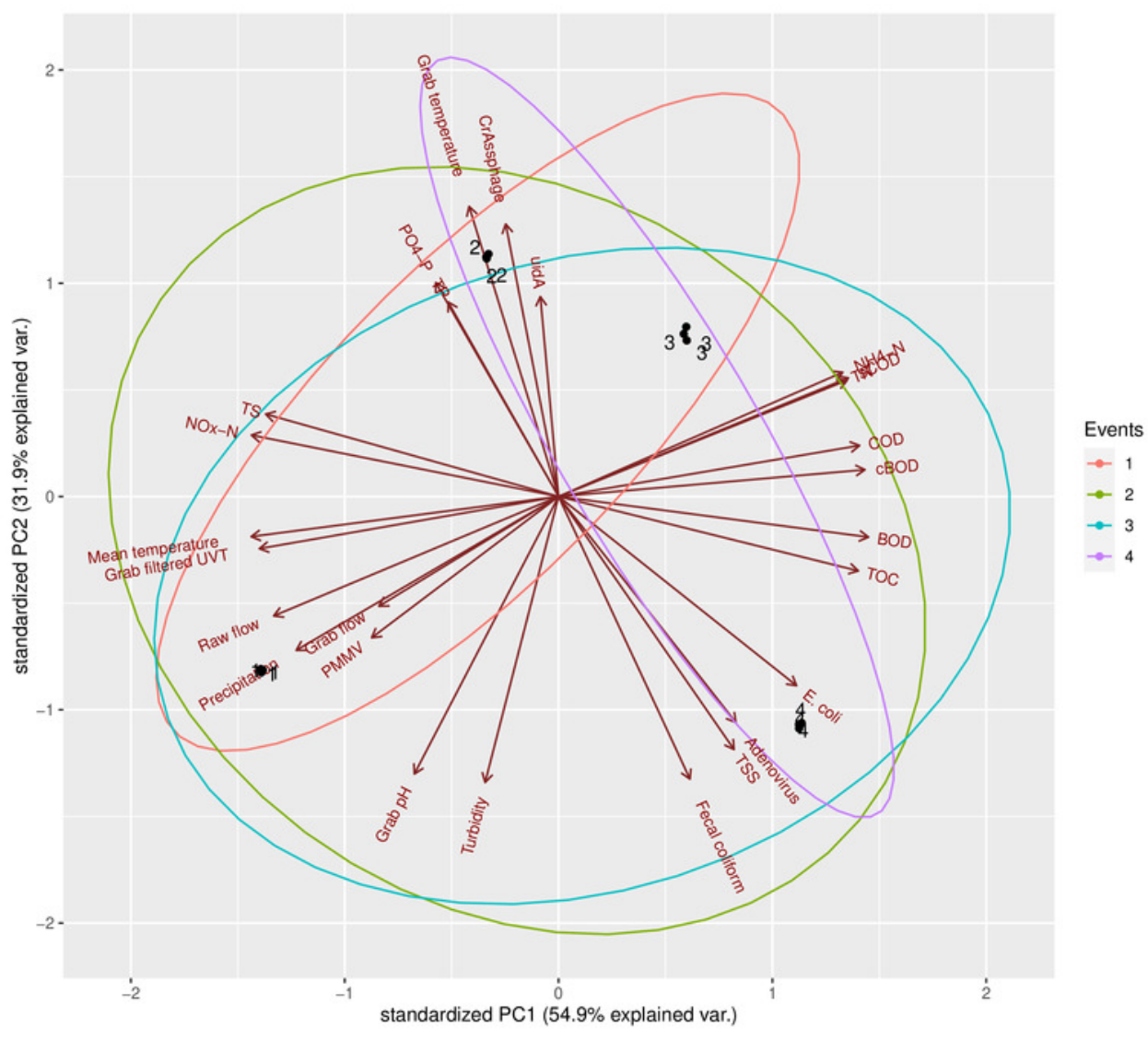




\section{Figure 6}

Figure 6. Heatmap showing Spearman's rank correlation analysis between parameters collected for EF sampling events.



